\title{
iletișim Fakültesi
}

Öğrencilerinin Medya Emek

Piyasasına Dönük Algı ve

\section{Beklentileri}

Ankara Örneği

\section{Çağrı Kaderoğlu Bulut}

Ankara Üniversitesi Illetișim Fakültesi

https://orcid.org/0000-0002-4701-9759

cagrikaderoglu@gmail.com
Elif Hacısalihoğlu

Trakya Üni. Iktisadi ve Idari Bilimler Fakültesi

https://orcid.org/0000-0003-3003-663X

elifhasal@gmail.com

\section{Öz}

Bu çalıșma iletișim fakültesi öğrencilerinin medya emek piyasasına dönük algı ve beklentilerini incelemektedir. Söz konusu algı ve beklentilerin, eğitim-istihdam ilișkisinin yapısı ve medya emek piyasasının koșulları ekseninde șekillendiği söylenebilir. Bu kapsamda çalıșmada ilk olarak eğitim-istihdam ilișkisinin dönüșen yapısı ele alınmakta, ikinci bölümde Türkiye'de medya emek piyasasının durumu irdelenmektedir. Üçüncü bölümde araștırmanın kapsamı ve yöntemi serimlenmekte ve son bölümde saha araștırmasının bulguları tartıșılmaktadır. Çalıșma, Ankara örneğinde 240 öğrenci ile yüz yüze anket yoluyla yapılan saha araștırmasına dayanmaktadır. Araștırmanın bulguları "öğrencilerin demografik ve sosyal profili", "iș bulma umudu ve kanalları," "çalıșma koșulları ve ortamı", "mesleğin anlamı ve toplumsal yararı", "eğitim süreci ve eğitim-istihdam ilișkisi" temaları ekseninde incelenmiștir. Iletișim fakültesi öğrencilerinin medya emek piyasasına dönük algı ve beklentilerinin, genç neslin yalnızca kendi meslek pratiklerine ve geleceklerine dönük değerlendirmelerini değil, aynı zamanda ülkenin ve mevcut toplumsal yapının geneline ilișkin ipuçlarını da barındırdı ğı belirtilebilir.

Anahtar Kelimeler: Medya emek piyasası, eğitim-istihdam ilișkisi, medya endüstrisi, iletișim eğitimi, iletișim fakültesi öğrencileri, genç ișgücü.

Makale geliș tarihi: 19.10.2020 - Makale kabul tarihi: 12.02.2020

http://ilefdergisi.org

ilef dergisi • (c) 2021 • 8(2) • güz/autumn: 261-295

Araștırma makalesi DOl: 10.24955/ilef.901414 


\section{The Perceptions and}

\section{Expectations of Students of}

Communication Faculty for

\section{the Media Labor Market}

\section{The Case of Ankara}

\section{Çağrı Kaderoğ/u Bulut}

Ankara University Faculty of Communication

https:/lorcid.org/0000-0002-4701-9759

cagrikaderoglu@gmail.com
Elif Hacısalihoğ/u

Trakya Uni. Fac of Economic and Adm. Science https:/lorcid.org/0000-0003-3003-663X

elifhasal@gmail.com

\section{Abstract}

This study examines communication faculty students' perceptions and expectations towards the media labour market in Turkey. It can be said that these perceptions and expectations are shaped around the structure of the education-employment relationship and the conditions of the media labour market. In this context, this study primarily deals with transforming structure of the education-employment relationship. Media labour market situation in Turkey is examined in the second part of the study. In the third part, the scope and method of the research are displayed, and the findings of the field research are discussed in the last part of the article. The study is based on a field study, conducted with 240 students by using face-to-face questionnaire, in Ankara. The findings of the study were examined in the axis of "demographic and social profile of the students", "the hope and ways of finding a job", "working conditions and environment", "meaning and social benefit of the profession" and "the education process and education- employment relationship in the sector". It can be stated that the perceptions and expectations of the communication faculty students towards the media labor market contain not only the opinions of the young generation about their own professional practices and future but also the clues about the country and the current social structure in general.

Keywords: Media labor market, education-employment relationship, media industry, communication education, communication faculty students.

\section{, י}

Received: 19.10.2020 - Accepted: 12.02.2020

http://ilefdergisi.org

ilef dergisi • (c) 2021 • 8(2) • güz/autumn: 261-295

Research Article DOI: 10.24955/ilef.901414 
Medya, günümüzün en önemli toplumsal kurumlarından biri olması nedeniyle pek çok araştırma ve tartışmaya konu olmaktadır. Bu çalışmalar çoğunlukla medya içerikleri, medya sahipliği, çalışma koşulları, medya kullanım pratikleri ve medya-demokrasi ilişkisi ekseninde yoğunlaşmaktadır. Benzer şekilde, iletişim fakültesi öğrencileri üzerine de oldukça geniş bir Türkçe literatür bulunmaktadır. Bu literatürün izlenebileceği önemli mecralardan biri ULAKBİM sistemidir. Bu sistemde Ekim 2020 tarihi itibariyle iletişim fakültesi öğrencileri üzerine yazılmış 189 makale ve e-kitaba ulaşılmıştır. Bu çalışmalarda iletişim fakültesi öğrencilerinin kimlik inşa süreçleri, medya ve sosyal medya kullanım pratikleri, eğitim sürecine dönük tutum ve yaklaşımları, dijital aktivizm pratikleri, internetle bağlantılı yaşam pratikleri, marka ve tüketicilik süreçleri ve medya okuryazarlığı düzeyleri gibi oldukça çeşitli konular incelenmektedir. $^{1}$

1 Literatürün genişliği nedeniyle çalışmaların tümüne burada referans vermek mümkün değildir. Konuyla ilgili tüm çalışmalara ulaşmak için bkz.

http: / / eds.b.ebscohost.com / eds / results?vid=5\&sid=5c37a179-543e-451b-93cdbf92cf3c3cbb $\% 40$ pdc-v-sessmgr04\&bquery $=\mathrm{TX} \% 2 \mathrm{~b} \% 2522$ ileti $\% 25 \mathrm{c} 5 \% 259$ fim $\% 2 \mathrm{bfak} \% 25 \mathrm{c} 3 \%$ 25bcltesi $\% 2 \mathrm{~b} \% 25 \mathrm{c} 3 \% 25 \mathrm{~b} 6 \% 25 \mathrm{c} 4 \% 259$ frencileri $\% 2522 \& b d a t a=J \mathrm{kF} 1 \mathrm{dGhUeXBIPXNzbyZjbGk}$ wPUZUMSZjbHYwPVkmbGFuZz10ciZ0eXBIPTAmc2VhcmNoTW9kZT1BbmQmc210ZT11Z HMtbGl2ZSZzY29wZT1zaXRl 
Literatürün bu geniş kapsamına karşın bir bütün olarak iletişim fakültesi öğrencilerinin medya emek piyasasına dönük yaklaşımlarını inceleyen hiçbir çalışmaya ulaşılamamıştır. Medya gibi zorlu bir alanda iş ve meslek yaşamlarının arifesinde olan iletişim fakültesi öğrencilerine dönük bu boşluk oldukça düşündürücüdür. Oysa iletişim fakültesi öğrencilerinin medya emek piyasasına dönük algı ve beklentilerini incelemek, genç neslin bir yandan kendi meslek pratiklerine ve geleceklerine dönük kanaatlerini açığa çıkarmak için önemli iken, diğer yandan ise gençlerin, yaşadıkları ülkenin mevcut durumuna ve geleceğine dönük beklentileri hakkında ipuçları yakalayabilmek açısından anlamlıdır. Dolayısıyla böylesi bir çalışma iletişim alanı özelinde gençlerin umutlarını, umutsuzluklarını ve sorunlarını görünür kılmak açısından gereklidir. Aynı zamanda böylesi bir araştırmanın sonuçları, iletişim alanının eğitimsel ve sektörel geleceğine ilişkin politika üretme süreçlerini de yeniden düşünme olanağı sunmaktadır.

$\mathrm{Bu}$ araştırma, bahsedilen hedeflerin tümünü gerçekleştirme iddiasında olmamakla birlikte, bu süreçte literatürdeki boşluğa bir katkı sunma ve alana ilişkin ön notlar sağlama amacını taşımaktadır. Çalışmada ilk olarak, eğitim-istihdam ilişkisi tartışılacak ve neoliberal dönemde bu ilişkinin dönüşen yapısına değinilecektir. Zira eğitim-istihdam arasındaki ilişkinin neoliberal dönemde aldığı yeni form, günümüzde üniversite eğitiminin amacını, işlevini ve içeriğini etkileyen en önemli unsurlardan biri olarak ortaya çıkmaktadır. Medya endüstrisi de bu ilişkinin kristalize olduğu alanlardan biridir. Bu kapsamda çalışmanın ikinci bölümünde araştırmanın bağlamını oluşturan medya emek piyasası ele alınarak piyasanın yapısı, kapsamı, işgücü ve istihdam verileri gibi göstergeler incelenecektir. Üçüncü bölümde araştırmanın kapsamı ve yöntemi açıklanacak, son bölümde ise bulgular belirli kategoriler altında serimlenerek tartışılacaktır.

\section{Neoliberal Dönemde Eğitim-İstihdam İlișkisi}

Kapitalist toplumsal ilişkilerin tarihsel gelişimi, eğitim olgusunu önemli ölçüde şekillendirmiştir. Eğitimin kurumsallaşması, yaygınlaşması, toplumsal işlevinin ve içeriğinin belirlenmesi ile kapitalizmin gelişimi arasında bir koşutluktan söz etmek mümkündür. ${ }^{2}$ Sermaye temelinde iş bölümüne dayalı bir toplumsal yapının gelişmesiyle modern mesleklerin ortaya çıkışı ve yeni bir işgücüne duyulan ihtiyaç, kapitalizm ve eğitim arasındaki temel bağı oluşturmaktadır. Kapitalizmde eğitim, en temelde işgücünün üretimi ve bu yolla

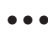

2 Tarihsel seyir içerisinde, eğitime yönelik farklı yaklaşımlar için bkz. İnal (2013, 265-287). 
toplumun yeniden üretimine yaslanır (Rikowski 2018, 161). Buna karşın, kapitalizmin yükseliş dönemlerinde modern toplumun inşası ve yeniden üretimi sürecinde yurttaşlık pratikleri ve dünyaya ilişkin kapsamlı bilgi ve düşünce üretimi de eğitimin işlevleri arasında yer almıştır (Ünal 2005, 38; Ünal 2013, 10-11). 20. yüzyılın son çeyreğinden günümüze gelen süreç ise kapitalizmin neoliberal dönüşümüyle birlikte eğitimin de yeniden yapılandırılmasını ortaya çıkarmıştır. Bu süreç, toplumsal, kurumsal ve içerik bakımından eğitimin piyasalaştırılmasını ve tüm yönleriyle kapitalist sermaye dinamiklerine bağlı kılınmasını içerir. Bu dönemde insanlar "[y]aşadığı çevre ve kendisini geliştirerek kendisi ve çevresi hakkında bilgiye sahip olan ve bu bilgiden hareketle seçimlerini yapan ve yaşam ortamını dönüştüren" bireylerden, "kapitalist ekonomik gelişmenin temel değişkenleri olan etkinlik, verimlilik ve rasyonalite koşullarının yaratılması amacına yönelmiştir" (Ercan 1998, 61). Dolayısıyla eğitimin amacı ve içeriği de bu hedefler doğrultusunda yeniden tanımlanmaktadır.

Bugünün sıklıkla sermaye sınıfı/işveren kesiminden duyulan, “üniversitenin öğrencileri işgücü piyasasına hazırlamadığı", "piyasanın ihtiyacı ile verilen eğitimin uyumlu olmadığı" yönündeki eleştirilerdeki ${ }^{3}$ anlayışa zemin sunan, eğitimin toplum içindeki yeri ve işlevindeki bu dönüşümdür.

Ekonomi politikalarında piyasalaştırma ve özelleştirme tabanında inşa edilen bu tip bir dönüşüm, eğitimin farklı düzeylerine yönelik farklı yaklaşımlara neden olmuştur. ${ }^{4}$ 1980'lerde Dünya Bankası (DB) ve Uluslararası Para Fonu (IMF) önderliğinde uygulamaya geçirilen yapısal uyum programları, eğitime toplumsal olarak yüklenen anlamın değişmesine hizmet edecek reformların gündeme taşınmasını sağlamıştır. Bu reformlar eğitimin amacının, işlevinin, bir kamusal hizmet olarak örgütlenerek kitlelere sunumunun yanında, müfredatını ve finansmanını düzenlemekte; eğitimin toplumsal eşitsizliği gidermede üstlendiği eşitlikçi rolde, toplumsal misyonunda ve organizasyonunda değişikliklere yol açmakta, böylelikle de eğitimi küresel kapitalist sisteme uyumlu hale getirmektedir (Sayılan 2006, 44; Torres ve Schugurensky

\section{$\bullet \bullet$}

3 Üniversitelerin "çağın beklentilerinden uzak eğitim anlayışı ve mesleki eğitime önem verilmemesi" ne yönelik eleştirildiği "Gençler de İşveren de Aradığını Bulamıyor" başlıklı bir haber için bkz. https:/ / www.milliyet.com.tr/gundem/gencler-de-isveren-de-aradiginibulamiyor-6013904

4 Yükseköğretim bireysel faydasının toplumsal faydaya kıyasla daha yüksek olduğu, bu nedenle de kişilerin hizmetin faydaları karşısında maliyetini kendilerinin yüklenmesi gerektiği, bu yaklaşımlardan biridir (Psacharopoulos'tan akt. Ercan, 1998: 74). 
2002). Dolayısıyla sistemi etkileyen çok geniş ve kapsayıcı bir müdahaleler bütünü söz konusudur.

Bu müdahalelerin bir ayağı da emek piyasalarına yaslanmaktadır. Neoliberal dönüşüm emek piyasaları üzerinde önemli etkiler yaratmıştır. Bir yandan iş ve mesleklerin yapısında değişimler yaşanmış, diğer yandan ise ihtiyaç duyulan emek gücünün niteliği farklılaşmıştır. Bu süreçte ihtiyaç duyulan yeni işgücünün yalnız beceriler temelinde değil, ideolojik ve politik olarak da yeni döneme uyumlu hale getirilmesinde eğitim en önemli unsurlardan biri olmuştur.

Eğitimin basamakları içerisinde ise yükseköğretim oldukça belirleyici bir konumda bulunmaktadır. Üniversite eğitimi, piyasalaşmanın gerektirdiği bilgi birikimini üretme ve piyasanın gereklerine uygun eleman yetiştirme ihtiyacını karşılama gibi beklentilerin doğrudan hedefi olmuştur. Bu kapsamda bir yandan üniversite eğitimi yaygınlaşmış, diğer yandan piyasa ile kurulan yakın ilişkilerin yansıması olarak akademik üretimi de etkileyecek biçimde üniversitenin işlevinde ve içeriğinde ciddi bir farklılaşma yaşanmıştır (Davies, Gottsche ve Bansel 2006).

Bu süreçte üniversite sayılarının artışı, üniversite eğitiminin niteliksizleşmesi ve giderek artan sayıda mezun verilmesi önemli bir sorun kaynağı oluşturmaktadır. Hem dünyada hem de Türkiye' deki üniversite mezunu işsizlik rakamlarına bakıldığında ${ }^{5}$, emek piyasalarının mezunları emecek kapasiteye çoğunlukla sahip olamadığı görülmektedir. Bu sorunlar, derinleşen neoliberal uygulamaların yarattığı güvencesizlik gibi genel sorunlarla birleştiğinde üniversite eğitimi ayrıcalıklı işlevini kaybetmeye ve eskisine nazaran değersizleşmeye başlamıştır. Bu süreç, bir yandan eğitim aldığı alanda iş bulmakta zorlanan ve eksik istihdam koşullarında çalışan üniversite mezunları yaratmış, diğer yandan ise doğrudan eğitimli bir işsizler kitlesinin oluşmasına zemin hazırlamıştır.

$\mathrm{Bu}$ dönüşümün en çok etkilendiği alanlardan biri iletişim eğitimidir. Dünyada iletişim fakülteleri yeni oluşmakta olan medya endüstrisinin ele-.・

5 Uluslararası Çalışma Örgütü'nün (ILO, 2020) verilerine göre, dünya genelinde çalışan gençlerin toplam gençlik içindeki payı yüzde 36 seviyesinde bulunmaktadır. Çalışmayan gençler içinde ise üniversite mezunu işsizlerin ortalaması Avrupa ülkeleri için 2018 yılında yüzde 3,9 (Eurostat, 2019), ABD için ise Haziran 2020 itibariyle yüzde 7,9'dur (Federal Reserve Bank of New York, 2020). Türkiye'de ise üniversite mezunu işsizlerin oranı 2019 yılı itibariyle yüzde 13,7'ye ulaşmış durumdadır (TÜİK, 2020a). 
man ihtiyacını karşılamak üzere 20. yüzyılın başında kurulmaya başlamış, Türkiye gibi geç kapitalistleşen ülkelerde ise iletişim eğitimi, 1950'lerin ikinci yarısından itibaren gelişmiştir (Can 2018, 59-60). Dolayısıyla iletişim fakültelerinin kurulması ve medyanın endüstrileşmesi arasında önemli bir bağlantı olduğu söylenebilir. 1980'ler ve 1990'larda ise neoliberal politikalara paralel şekilde medya endüstrisinde holdingleşme ve yoğunlaşma dönemi yaşanırken iletişim fakültelerinin sayısı da artmaya başlamıştır. Özellikle 1990'larla birlikte medya da hem mecra hem sektör olarak genişlemiş ve çeşitlenmiştir. Bu süreç emek piyasasında da karşılığını bulmuştur. Dolayısıyla eğitim ve istihdam arasındaki ilişki medya piyasasının değişimine paralel olarak şekillenmiştir. Günümüzde medya emek piyasasının durumunu incelemek, bu ilişkinin güncel boyutlarını serimlemek açısından gereklidir. Sonraki bölüm bu tartışmaya ayrılmıştır.

\section{Türkiye'de Medya Emek Piyasası}

Türkiye' de medya emek piyasası kimi tarihsel dönüşümler ışığında açıklanabilir. Türkiye ekonomisinin 1980'de 24 Ocak kararları ve 12 Eylül darbesiyle ivmelenen neoliberal dönüşümü medya endüstrisinde de karşılığını bulmuştur. Medyanın dönüşümü iktisadi ve siyasi-ideolojik olarak iki boyutu kapsar. İktisadi dönüşüm, asıl işi medya faaliyeti olmayan büyük sermaye gruplarının bu alana girmesiyle medyada artan ticarileşme, holdingleşme, yoğunlaşma ve uluslararasılaşma olarak gerçekleşmiştir. Siyasi-ideolojik dönüşüm ise, medya gruplarının siyasal iktidarla giderek artan ilişkileri, toplumsal rıza üretiminde medyanın etkin rolü ve tüketim süreçleri için önemli bir teşvik edici mekanizma olması şeklinde ortaya çıkmıştır (Kaya 1999; Adaklı 2009, 286-287; Bulut 2020, 102). Dolayısıyla medya, 1980 sonrası hem önemli dönüşümlerden geçmiş hem de toplumun bir bütün olarak dönüştürülmesi bakımından oldukça önemli bir rol oynamıştır. AKP döneminde ise, medyaiktidar ilişkileri, siyasetin otoriter yapısına bağlı olarak ekonomik, siyasi ve ideolojik olarak bütünleşmiş ve medya bir yandan iktidar için toplumsal süreçlere müdahale aracı, diğer yandan ise iktidar ve sermaye grupları arasında ekonomik bir ilişkiler ağı haline gelmiştir (Seçkin 2020, 218-219, 222; Kaya 2016, 255-257; Aydın 2014, 134-136; Sözeri 2015, 12-15).

$\mathrm{Bu}$ tarihsel süreç, medyada yeni ekonomik-toplumsal yapıya uygun bir çalışma düzeninin ve ilişkilerinin ortaya çıkmasına zemin hazırlamıştır. 1980'lerden itibaren giderek artan düzeyde çalışma ilişkileri güvencesiz, kuralsız, esnek, bireysel iş hukukuna dayalı ve örgütsüz bir hale dönüşmüştür. Son dönemde ise bu koşulların çok daha derinleştiği ve siyasal iktidarın 
müdahaleleriyle iç içe geçtiği bir çalışma düzeni ortaya çıkmıştır (Önderoğlu 2015; Ekşioğlu Sarılar 2016, 135-136; Kaya 2016, 266-267). Bunun yanı sıra özellikle 2000'lerden sonra hızlanan dijitalleşme süreçleri de medya endüstrisinde önemli değişimler yaratmış, mecraları, içerik türlerini, iş modellerini ve çalışma biçimlerini etkilemiştir. Mecralar ve içerik türleri dijitalleşme sürecinde çeşitlenirken, dijital alanlara dayalı yeni iş modelleri ortaya çıkmıştır. Çalışma biçimlerinde ise dijitalleşme bir yandan kimi yeni formların (freelance çalışma gibi) yaygınlaşmasına ve dijital doğumlu yeni medya kuruluşlarının oluşmasına neden olurken, diğer yandan emek piyasasında var olan güvencesizleşme ve kuralsızlaşma gibi olumsuz eğilimleri de derinleştirici bir etkide bulunmuştur (Çamuroğlu Çı̆̆ ve Çı̆̆ 2015; Uzunoğlu 2018). Dolayısıyla derinleşmiş neoliberal uygulamalar, siyasi otoriterleşme ve dijital dönüşümün günümüzde Türkiye' deki medya emek piyasasını şekillendiren en önemli unsurlar olduğunu söylemek mümkündür.

Medya endüstrisinin ve emek piyasasının içeriği bu genel eğilimler bağlamında incelenebilir. Medya endüstrisi günümüzde gazete, televizyon ve radyo gibi kitle iletişim araçlarının yanı sıra yeni medya alanlarını da kapsayan oldukça geniş bir uzama sahiptir. Bu açıdan medya endüstrisi haber üretiminden reklamcılığa, program ve film yapımcılığından yeni medya ortamlarında içerik/hizmet üretimine, internet editörlüğünden sosyal medya yönetimine, ajans faaliyetlerinden yayıncılığa kadar birçok farklı fakat birbiriyle ilişkili çalışma alanını içermektedir. Medya emek piyasasının durumunu ve yapısını tespit edebilmek için öncelikle bu alanlara ilişkin temel verileri ele almak açıklayıcı olacaktır. Bu noktada önemli bir zorluktan bahsetmek gerekir: Medya endüstrisinde hem kayıtdışı hem de kayıtlı çalışanlara ilişkin tam ve sağlıklı veriye ulaşılması oldukça güçtür. Sönmez'in $(2013,24)$ belirttiği gibi hiçbir sektörel kodlamada "medya endüstrisi" başlıklı bir veri seti bulunmamaktadır. Bunun yerine, sektörün çeşitli alt bileşenlerini bir araya getirerek hesaplamalar yapılmaktadır.

Medya endüstrisini oluşturan alt bileşenleri NACE sınıflandırmasında$\mathrm{ki}^{6}$ faaliyet alanlarına göre tespit etmek ve yaklaşık da olsa kimi sonuçlara ulaşmak mümkündür. NACE sınıflandırmasında medya emek piyasasını tespit edebileceğimiz alt alanlar ve kodları şöyle sıralanabilir: Sinema filmi, video ve televizyon programları yapımcılı̆̆ı, ses kaydı ve müzik yayımlama faaliyetleri (59); Programcılık ve yayıncılık faaliyetleri (60); Bilgi hizmet faaliyetleri (63); İdare

\section{•••}

6 Avrupa'da ekonomik faaliyetlerin istatistiki sınıflandırmasını sağlayan kodlama sistemidir. Açılımı "Nomenclature générale des Activités économiques dans les Communautés Européennes" şeklindedir. 
merkezi faaliyetleri ve idari danışmanlık faaliyetleri (halkla ilişkiler ve iletişim faaliyetleri) (70); Reklamcılık ve piyasa araştırması (73). ${ }^{7}$ Bu faaliyet alanları aynı zamanda yine NACE meslek kodlamasında 30 numaralı “Bilgi, İletişim ve Medya" meslek grubunu oluşturmaktadır. Bu alanlar yazılı, görsel, işitsel medya ile web portallarını ve halkla ilişkiler ve reklamcılık faaliyetlerini kapsamaktadır. Bu nedenle, iletişim fakültelerindeki eğitim alanlarına denk gelen bir emek piyasası resmi ortaya koyabilmek açısından elverişli olduğu söylenebilir.

Türkiye' de medya emek piyasasının kapsamını tespit edebilmek için söz konusu alanlardaki işyeri ve istihdam verilerini incelemek önemlidir. Sosyal Güvenlik Kurumu'nun (SGK) NACE sınıflandırmasına dayanarak geliştirdiği 2019 yılı verilerine göre, 59 kodlu faaliyet alanında 2 bin 209 işyeri, 23 bin 444 çalışan; 60 kodlu faaliyet alanında 739 işyeri, 9 bin 753 çalışan; 63 kodlu faaliyet alanında 1907 işyeri ve 43 bin 419 çalışan; 70 kodlu faaliyet alanında 19 bin 324 işyeri, 212 bin 504 çalışan; 73 kodlu faaliyet alanında ise 7 bin 227 işyeri ve 58 bin 571 çalışan bulunmaktadır (SGK 2019a). Medya endüstrisindeki toplam kayıtlı istihdam 347 bin 691 olarak ortaya çıkmaktadır. Buradan hareketle, medya endüstrisinin Türkiye'deki toplam kayıtlı istihdamın (22 milyon 964 kişi, SGK 2019a) yaklaşık yüzde 1,5'ini oluşturduğu söylenebilir.

Bu genel tablonun yanı sıra yazılı, görsel, işitsel ve dijital medya ile halkla ilişkiler ve reklamcılık alanına ilişkin kimi ayrıntılı verilere ulaşmak da mümkündür. Yazılı medya, gazete ve dergi yayıncılığını kapsamaktadır. 2019 yılı itibariyle Türkiye'de 171 ulusal, 45 bölgesel ve 2 bin 121 yerel olmak üzere toplam 2 bin 337 gazete; 2 bin 76'sı ulusal, 143'ü bölgesel ve 929'u yerel olmak üzere toplam 3 bin 148 dergi yayınlanmaktadır. Ulusal yayın yapan gazeteler, toplam gazetelerin yüzde 7,3'ünü oluşturmasına karşın tirajların yüzde 83,6 'sına sahiptir. Dergilerin ise yüzde 65,9'u ulusal yayın yapmakta ve tirajların yüzde 83,7'sine sahip olmaktadır (TÜIK 2020b). Buradan hareketle yerel yazılı basının kapsamının ve etkinliğinin oldukça geri planda kaldığı söylenebilir. Bu alandaki istihdam verileri de önemlidir. TÜİK (2020b) verilerine göre yazılı basında (basım ve dağıtım işlerinde çalışanlar dışarıda bırakılıp doğrudan yayıncılık departmanlarında istihdam edilenler dikkate alındığında) kayıtlı çalışan sayısı 2019 yılı itibariyle 36 bin 263 kişidir. Dolayısıyla medya emek piyasasında toplam çalışan sayısının yaklaşık yüzde 10'unun (her 10 kişiden 1'inin) yazılı gazete ve dergilerde istihdam edildiği söylenebilir.

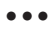

7 NACE sınıflandırmasının sıralı tam içeriği için bkz. https:/ / ec.europa.eu/competition/mergers / cases / index/nace_all.html 
Görsel ve işitsel yayıncılık alanına dönük güncel veriler ise Radyo Televizyon Yayıncıları Meslek Birliği'nin (RATEM) sektör raporlarından takip edilebilmektedir. ${ }^{8}$ Buna göre Türkiye' de görsel yayıncılık alanında 2018 yılı sonu itibariyle 144 adet karasal analog televizyon kuruluşu yayın yapmaktadır. Bunlardan 15'i ulusal, 3'ü bölgesel, 126'sı ise yerel yayıncıdır. Bunun yanı sıra kablolu yayında 181, uydu yayınında ise 374 adet televizyon kuruluşu mevcuttur. 2018 sonu itibariyle Türkiye' de yayın yapan toplam 699 adet televizyon bulunmaktadır (RATEM 2019, 66-67, 71). İsitsel yayıncllıta ise 2018 sonu itibariyle 32 ulusal, 76 bölgesel, 750 yerel olmak üzere toplam 858 adet analog FM radyo kuruluşuna ek olarak kablolu yayında 8, uydu yayınında ise 101 radyo bulunmaktadır. Toplamda 967 adet radyo istasyonu yayındadır (RATEM 2019, 48-50). Radyo ve televizyonlarda istihdam edilen çalışan sayısı hakkında tam bir veriye ulaşmak mümkün olamamaktadır. Medya endüstrisinin geniş ve karmaşık yapısı ve yukarıda değinilen güçlükler nedeniyle endüstrideki istihdam verilerini açık ve net şekilde elde etmek oldukça zordur.

Bunun yanı sıra kamu kuruluşu niteliğindeki TRT de medya endüstrisinde önemli bir yer kaplamaktadır. TRT, 13 televizyon kanalı, 14 radyo kanalı, 2 online site ve 3 basılı dergi ile medyada varlık göstermektedir. 2019 yılı itibariyle TRT'de yaklaşık 5 bin 300 personel istihdam edilmektedir. ${ }^{9}$

Dijital medya alanı ise oldukça geniş ve hareketli bir yapıya sahiptir. Burada bir yandan yazılı-görsel-işitsel alandaki geleneksel medya yapılarının internet kuruluşları, diğer yandan ise dijital doğumlu ve yalnızca internet üzerinden yayın yapan medya kuruluşları bulunmaktadır. Dijital doğumlu medya kuruluşlarının büyük bölümü haber medyası kategorisinde bulunmaktadır. Hem oldukça hızlı değişiyor olması hem de kayıtdışılığın ve işgücü hareketliliğinin oldukça yüksek olması gibi nedenlerle bu alanın tam verilerine ulaşmak mümkün olamamaktadır. Buna karşın Demir, Türkiye'de dijitalde doğan ve yalnızca bu alanda yayın yapan en az 80 ulusal haber sitesi olduğunu; yerel ya da bölgesel ölçekte dijital habercilik yapan ise yaklaşık 600 internet sitesi olduğunu belirtir (2019, 100, 256-258). Similarweb ölçüm şirketi-

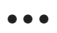

8 Bu konuda TÜIK'in hazırladığı Radyo Televizyon Kurum İstatistikleri ve RTÜK tarafından hazırlanan Radyo Televizyon Yayıncılı̆̆ı Sektör Raporu 2016 yılından bu yana yayınlanmamaktadır. Bu alandaki en güncel verilere RATEM raporlarında ulaşılmıştır.

92016 yılından bu yana faaliyet raporu yayınlamayan TRT'deki istihdam sık sık tartışma konusu olmaktadır. İstihdama ilişkin burada kullanılan verilere TBMM'de TRT hakkında verilen bir soru önergesine Cumhurbaşkanı Yardımcısı Fuat Oktay tarafından verilen yanıttan ulaşılmıştır. İlgili soru önergesi ve yanıt için bkz. https: / / www2.tbmm.gov.tr / d27 / 7/ 7-8286sgc. pdf 
nin ${ }^{10}$ Temmuz 2020 verilerine göre ise, Türkiye' de en çok ziyaret edilen 50 site içerisinde dijitalde doğan ya da geleneksel medyanın dijital uzantısı olan 18 haber sitesi bulunmaktadır. Bu siteler, küçük ve orta ölçekli de olsa istihdam sağlamak açısından önemlidir.

Yazılı, görsel, işitsel ve dijital medyanın ardından, medya emek piyasasının önemli bir bileşeni olan halkla ilişkiler ve reklamcılık alanındaki işyeri ve istihdam verilerine bakılabilir. Medya endüstrisinin diğer alanlarında olduğu gibi bu alanda da sağlıklı veri bulmak oldukça güçtür. İletişim Danışmanl1ğı Şirketleri Derneği'nin açıklamasına göre, halkla ilişkiler alanında 600'den fazla ajans ve ek olarak bireysel danışmanlık hizmeti veren halkla ilişkiler profesyoneli faaliyet göstermektedir (IDDA 2016). Buna karşın TÜİK verileri bu alanda 14 bin 647 girişim ve 54 bin 580 çalışan olduğunu işaret etmektedir. Reklamcılıkta da benzer bir durum söz konusudur (2020c). Reklamcılar derneğine üye 86 reklam ajansı bulunmaktadır. Bununla birlikte alanda 15 bin 510 girişim ve 64 bin 548 ücretli çalışan olduğu saptanmaktadır (TÜİK 2020c). İlgili alandaki sektör kuruluşları ile TÜİK verileri arasındaki bu farkın, sektör kuruluşlarının çoğunlukla İstanbul-Ankara merkezli bir yaklaşıma sahip olmasına karşın TÜİK'in tüm Türkiye'yi ve ticari kaydı bu alanda olan tüm işletmeleri istatistiklere dâhil etmesinden kaynaklandığı düşünülebilir.

Medya endüstrisinin kapsamını işaret eden bu verilerin yanı sıra, sektöre işgücü yetiştiren iletişim fakülteleri ve bu fakültelerdeki öğrenci sayısı da emek piyasasının boyutlarını işaret etmesi bakımından önemlidir. YÖK'ün 2019-2020 yükseköğretim istatistiklerine göre Türkiye' de 61 iletişim fakültesi bulunmaktadır. Bu fakültelerdeki öğrenci sayısı 81 bin 590 kişidir. Bu fakültelerden 2019 yılında mezun olan öğrenci sayısı ise 8395'tir (YÖK 2020). YÖK verilerine göre iletişim fakültelerinden her yıl 8 bin civarında öğrenci mezun olmaktadır. Buna karşın, iletişim fakültelerinden mezun olanların işsizlik oranlarının yüksekliği göze çarpmaktadır. Genel olarak üniversite mezunlarının 2019 yılı itibariyle işgücüne katılım oranı yüzde 79,3, işsizlik oranı ise yüzde 13,7' dir (TÜÍK 2020a). İletişim fakültesi mezunlarında ise işsizlik Türkiye ortalamasının oldukça üzerinde seyretmektedir. TÜİK verilerine göre, üniversite mezunu işsizler arasında gazetecilik ve enformasyon alanlarından mezun olanlarda işsizlik yüzde 21,8 olarak tespit edilmiştir. Bu alanda işgücüne katılım oranı da yüzde 74,0 ile genel ortalamanın altındadır (TÜİK 2020a). Dolayısıyla iletişim fakültesi mezunlarında hem işgücüne katılım görece düşük hem de işgücüne katılanlar arasında işsizlik oldukça yüksektir. Bu alanda 10 Bkz. https://www.similarweb.com/top-websites/turkey/ 
her 5 mezundan birinin işsiz olduğu, çok daha fazlasının ise kendi mezun olduğu alanlarda iş bulamadığı söylenebilir. Kızılca ve Karagöz-Kızılca yaptıkları araştırmada iletişim mezunları arasında bölümleriyle doğrudan ilgili mesleklerle uğraşanların oranının yüzde 20'nin altında kaldığını belirtmektedirler $(2018,20){ }^{11}$

Bu durumun görece kalıcı bir manzara olduğu da son yılların TÜíK verileri incelendiğinde ortaya çıkmaktadır. Üniversite mezunu işsizler arasında gazetecilik ve enformasyon alanlarından mezun olanlar 2014 yılında ilk sırada (29,1); 2015 yılında altıncı sırada (yüzde 15,9); 2016 ve 2017 yıllarında dördüncü sırada (yüzde 19,2 ve 19,1); 2018 ve 2019 yıllarında ise ikinci sırada (yüzde 23,8 ve yüzde 21,8) yer almaktadır. Dolayısıyla iletişim fakültesi mezunlarının üniversite mezunu işsizler içerisinde sürekli ilk sıralarda yer aldığı ve yakıı bir işsizlikle karşı karşıya kaldıkları vurgulanmalıdır.

İşsiz sayılarının yüksekliğine karşın sektörde istihdam edilebilenlerin ise kayıtlı çalışma durumu, çalışma saatleri ve ücretler açısından zor koşullar altında olduğu belirtilebilir. Medya emek piyasasında kayıtdışı istihdam önemli bir sorun alanı olarak öne çıkar. SGK'nın verilerine göre, Bilgi ve İletişim faaliyet kolunda kayıtdışı istihdam oranı yüzde 12,39'dur (SGK 2019b). Çalışma sürelerinin uzunluğu da bir diğer önemli sorun alanıdır. Medya sektöründe çalışanlar, yasal çalışma süresi olan haftalık 45 saatin üzerinde, 47 saati aşan sürelerle çalışmaktadırlar (Kızılca ve Karagöz-Kızılca 2018, 25). Ücretler ise 2018 sonrası itibariyle reklamcllık, halkla ilişkiler ve yazıll-işitsel-görsel-dijital medya alanlarında ortalama 2000 ile $5000 \mathrm{TL}$ arasında seyretmektedir. ${ }^{12}$ Bununla birlikte ücretlerin 3500 TL civarında yoğunlaştığı tespit edilebilir (K1zılca ve Karagöz-Kızılca 2018, 24). Sektörde deneyim arttıkça ücretlerde üst sınıra yaklaşmak mümkün olabilmektedir. Bu göstergelerden hareketle med-..

11 Bu konuda önemli bir örnek de gazetecilik alanından verilebilir. Cumhurbaşkanlığ1 İletişim Merkezi'nin açıkladığına göre 2019 yılı itibariyle basın kartı taşıyan gazetecilerin yalnızca yüzde 10’u iletişim fakültesi mezunudur. Bkz. https: / / www.sozcu.com.tr/2019/gundem/ binlerce-iletisim-fakultesi-mezunu-issiz-5530266/

12 Reklam ve pazarlama alanındaki ücretlere ilişkin bir araştırma için bkz. https: / / bigumigu. com/haber/ bigumigu-reklam-ve-pazarlama-sektoru-gelir-arastirmasi-2018-sonuclar-2-3/; halkla ilişkiler alanındaki ücretlere ilişkin bir araştırma için bkz. https:/ / www.netmaaslari.com/2016/09/halkla-iliskiler-departman-maaslari.html; muhabirlik alanındaki ücretlere ilişkin bir araştırma için bkz. http:/ / www.kamuajans.com/maaslar/2020-yili-televizyonhaber-muhabirlerinin-temmuz-ayi-maaslari-ne-kadar-tv-muhabiri-maaslari-h551473.html. $\mathrm{Bu}$ ücretler, yönetici pozisyonlarda olanları kapsamamakta, sektörün genel ücret skalasını yansitmaktadir. 
ya endüstrisinde istihdam edilebilmenin de istihdam edildikten sonra görece olumlu koşullarda çalışabilmenin de oldukça güç olduğu söylenebilmektedir.

Medya emek piyasasının genel manzarası ve koşulları düşünüldüğünde iletişim fakültesi öğrencilerinin, eğitim hayatının ardından kendilerini nasıl bir çalışma hayatının beklediğine dönük algı ve beklentileri daha da önem kazanmaktadır. Öğrencilerin, mevcut koşulların ne kadar farkında oldukları, bu koşullara maddi ve psikolojik yönlerden hazırlıklı olup olmadıkları, mevcut durumla baş edebilmek için ne gibi stratejiler geliştirdikleri ve genel olarak bu koşulların sebeplerine dönük düşüncelerinin tespit edilmesi, iletişim öğrencilerinin bireysel, mesleki ve toplumsal geleceklerine dair zihin haritalarını ve içinde bulundukları şartları ortaya çıkarması bakımından anlamlıdır. İzleyen bölümlerde bu kapsamdaki saha araştırmasının bulguları tartışılacaktır.

\section{Araștırmanın Kapsamı ve Yöntemi}

İletişim fakültesi öğrencilerinin medya emek piyasasına dönük algı ve beklentilerinin Ankara örneğinde incelendiği bu araştırmanın kapsamını Ankara'daki iki büyük kamu üniversitesi olan Ankara Üniversitesi İletişim Fakültesi ve Hacı Bayram Veli Üniversitesi İletişim Fakültesi' ${ }^{13}$ öğrencileri oluşturmaktadır. Her ikisi de Türkiye'nin en köklü iletişim eğitimi kurumları olan bu üniversiteler, hem uzun yıllardır iletişim eğitimi vermeleri ve birer ekol halini almış olmaları, hem de öğrenci sayıları itibariyle tercih edilmiştir. YÖK'ün 2019-2020 yükseköğretim istatistiklerine (YÖK 2020) göre Ankara' da iletişim fakültesi düzeyinde eğitim gören toplam 3167 öğrencinin 2388'i bu iki üniversitede eğitim görmektedir. Ankara Üniversitesi İletişim Fakültesi'nde 1022, Hacı Bayram Veli Üniversitesi İletişim Fakültesi'nde ise 1366 kayıtlı öğrenci bulunmaktadir.

Çalışmada nicel araştırma desenine yaslanan betimsel yöntem kullanılmaktadır. Veri toplama tekniği olarak yapılandırılmış anket formu kullanılmıştır. Bu form üç bölümden oluşmaktadır. İlk bölümde araştırmaya katılanların demografik özelliklerini belirlemeye yönelik sorular bulunmaktadır. İkinci bölümde yanıtlayıcıların ve ailelerinin sosyo-ekonomik durumlarına

13 Hacı Bayram Veli Üniversitesi 2018 yılında Gazi Üniversitesi'nin bölünmesi ile eğitim hayatına başlamıştır. Hacı Bayram Veli Üniversitesi İletişim Fakültesi de bu süreçte kökleri 50 yılı bulan Gazi Üniversitesi İletişim Fakültesi'nin devri ile oluşmuştur. Bu nedenle Hacı Bayram Veli Üniversitesi İletişim Fakültesi her ne kadar kurumsal kimlik olarak yeniyse de fiilen Türkiye'nin ve Ankara'nın en önemli iletişim fakülteleri arasında yer almaya devam etmektedir. 
dönük sorular vardır. Son bölümde ise öğrencilerin medya emek piyasasına dönük algıları ve beklentilerini ölçebilmek üzere çoktan seçmeli sorular ve Likert ölçeğine dayalı yargı cümleleri yer almaktadır. Anketler, 15 Mart - 10 Mayıs 2019 tarihleri arasında, araştırma kapsamındaki iki üniversiteden 120'şer olmak üzere toplam 240 öğrenciyle yüz yüze gerçekleştirilmiştir. Örneklemin oluşturulmasında, öğrencilere ulaşma süreci ve ankete katılım konularındaki rızaları sınırlandırıcı bir etkide bulunmuştur. Örneklemin daha fazla genişletilememesi çalışmanın temel sınırlılığını oluşturmuştur.

Araştırmada tesadüfi olmayan örneklem türlerinden kota örneklem kullanılmıştır. Tesadüfi olmayan örneklemlerde üzerinde çalışılan nüfusun her biriminin örnekleme girme şansı eşit değildir. Üniversite öğrencileri arasında yapılan bu çalışmada da örneklem, üniversitede kaydı bulunan tüm öğrencilerden değil, okula ve derslere devam eden öğrenciler içinden seçilmiştir. Bu nedenle tesadüfi olmayan örnekleme dayanır. Geray, çalışılan nüfusun türdeş olması durumunda o türdeşliğin içinden tesadüfi olmayan yöntemlerle örneklem seçiminin de tüm nüfusa genellenebilir bir özelliğe sahip olduğunu belirtir (2011, 128). Bu çalışmada, çalışmanın evrenini ve örneklemini oluşturan nüfus "üniversite öğrencisi” olmaktan kaynaklı bir türdeşliğe sahiptir. Bailey bu örneklem yönteminin, birimlerin seçiminin titizlikle ve yanlılıklardan uzak kalarak yapılması durumunda genellenebilirlik taşıyacağını vurgular $(1987,93)$. Bu çalışmada da söz konusu unsurlar göz önünde bulundurulmuştur. Tesadüfi olmayan örneklem türlerinden olan kota örneklemde, evren, seçilen değişkenler açısından benzer alt gruplara ayrılır. Çalışılacak birim sayısı ise araştırmanın/araştırmacının olanakları çerçevesinde saptanır (Gökçe 1988, 83). Bu araştırmada da iletişim fakültelerinde okuyan öğrenciler öncelikle bölümler düzeyinde (Gazetecilik, Radyo-Televizyon-Sinema, Halkla İlişkiler ve Tanıtım) üç gruba ayrılmış, sonrasında her bölüm kendi içinde sınıflara (1., 2., 3., ve 4. sınıf) ayrılmış ve öğrenciler her bir bölümün her s1nıfından 10'ar kişi olmak üzere seçilmiştir. Dolayısıyla her bölümden 40'ar kişi, bir fakülteden ise 120 kişi olacak şekilde örneklem oluşturulmuştur. Aynı işlem araştırma kapsamındaki iki fakülte için gerçekleştirildiğinden örneklem büyüklüğü 240 öğrenci olarak şekillenmiştir. Örneklemin oluşturulmasında yukarıda değinilen sınırlılıklar geçerli olmuştur. Böylece her bir bölümün örneklem içindeki payı yüzde 33,3, her bölümün altındaki her bir sınıfın payı ise yüzde 8,3 olmuştur.

Verilerin analizinde SPSS 25.0 istatistik analiz programı kullanılmıştır. Değişkenlerin frekans dağılımları ve oran, ortalama gibi betimsel istatistik- 
lerin yanı sıra değişkenler arası farklılıkların analizi için t-testi, tek-yönlü varyans analizi (ANOVA), Tukey ve Games-Howell testleri, değişkenler arası ilişkilerin tespiti içinse korelasyon analizi uygulanmıştır. Analiz ve yorumlarda $\mathrm{p}<0,05$ anlamlılık düzeyi dikkate alınmıştır.

\section{Bulgular ve Tartıșma}

Araştırmanın bulguları serimlenirken ilk olarak öğrencilerin demografik ve sosyal profilinin belirlenmesi, ardından medya emek piyasasına dönük algı ve beklentilerinin incelenmesi gerçekleştirilecektir. Bu alg1 ve beklentiler "iş bulma umudu ve kanalları", "çalışma koşulları ve ortamı", "mesleğin anlamı ve toplumsal yararı", "eğitim süreci ve eğitim- istihdam ilişkisi” başlıkları altında incelenecektir.

\section{Öğrencilerin demografik ve sosyal profili}

Araştırmaya katılan öğrencilerin yüzde 51,2'si erkek, yüzde 48,8'i kadındır. YÖK'ün istatistikleri (YÖK 2020) temel alınarak yapılan hesaplamada Ankara'daki iletişim fakültesi öğrencilerinin yüzde 52,5'inin erkek, 47,5'inin kadın olduğu belirlenmiştir. Buradan hareketle örneklemdeki cinsiyet dağılımının Ankara genelindeki dağılım ile uyumlu olduğu belirtilebilir. Cinsiyetin yanı sıra yaş dağılımlarına bakıldığında, öğrencilerin yaşlarının ortalamasının 22 olduğu saptanmıştır.

Öğrencilerin profillerinin belirlenmesinde, üniversiteye gelmeden önce yaşadıkları yerleşim birimleri ve bölgeler önemli bir unsurdur. Öğrencilerin yüzde 63,7'si üniversiteye gelmeden önce büyükşehirde yaşarken, yüzde 15,4'ü büyükşehir olmayan bir ilde, yüzde 17'si ilçede, yüzde 3,8'i ise kasaba ve köyde yaşadıklarını belirtmişlerdir. Üniversite öncesinde yaşadıkları yerlerin bölgesel dağılımına bakıldığında ise ilk üç bölge sırasıyla İç Anadolu (yüzde 53,8), Marmara (yüzde 14,2) ve Karadeniz (yüzde 10,8) olarak tespit edilmektedir. Bunları Akdeniz (yüzde 9,6) ve Ege (yüzde 7,5) bölgeleri takip etmektedir. Güneydoğu Anadolu (yüzde 3,3) ve Doğu Anadolu (yüzde 0,8) bölgelerinden iletişim fakültesi eğitimi almak üzere Ankara'ya gelen öğrencilerin oranının düşüklüğü dikkat çekmektedir. Buradan hareketle iletişim fakültesi öğrencilerinin çoğunlukla Türkiye'nin orta ve batı bölgelerinden ve ağırlıklı olarak il bazlı ve büyükşehir ölçeğindeki birimlerden gelmiş olduğu söylenebilir. Dolayısıyla bu öğrencilerin büyük ölçüde kentsel ilişkiler ağı içerisinden üniversiteye dâhil olduğunu ve kentli bir kitle olarak eğitime girdiklerini söylemek mümkündür. 
Ailelerinin sosyo-ekonomik ve eğitsel yapıları da öğrencilerin profillerini belirlemede oldukça önemli bir göstergedir. Ebeveynlerin eğitim ve çalışma durumları öğrencilerin konumlarının ekonomik ve sosyal boyutları hakkında fikir vermektedir. Öğrencilerin büyük çoğunluğu, babasının işçi (yüzde 32,1) ve memur (yüzde 25,4) olduğu ailelerden gelmektedir. Çiftçi aileleri oldukça düşük (yüzde 2,9) bir orandadır. Babanın kendi hesabına çalışan/esnaf olduğu ailelerin oranı ise yüzde 18,3'tür. Öğrencilerin annelerinin çalışıp çalışmadığına dair sonuçlar da oldukça dikkat çekicidir. Öğrencilerin yarısından fazlası (yüzde 57,5) annelerinin çalışmadığını belirtmiştir. Diğer yandan öğrencilerin yüzde 15'i annelerinin işçi, yüzde 11,3'ü ise memur olduğunu ifade etmiştir. Kendi hesabına çalışan/ esnaf olan annelerin oranı oldukça düşüktür (yüzde 2,5). Annesinin çiftçi olduğunu söyleyenlerin oranı ise yüzde $0,8^{\prime}$ dir.

Tablo 1. Öğrencilerin Babalarının İ̦i

\begin{tabular}{|l|c|c|}
\hline & Sıklık & $\begin{array}{c}\text { Yüzde } \\
(\%)\end{array}$ \\
\hline Çiftçi & 7 & 2,9 \\
\hline Esnaf & 44 & 18,3 \\
\hline İşçi (ya da ișçi emeklisi) & 77 & 32,1 \\
\hline $\begin{array}{l}\text { Memur (ya da } \\
\text { memur emeklisi) }\end{array}$ & 61 & 25,4 \\
\hline Diğer & 49 & 20,4 \\
\hline
\end{tabular}

Tablo 2. Öğrencilerin Annelerinin İ̦i

\begin{tabular}{|l|c|c|}
\hline & Sıklık & $\begin{array}{c}\text { Yüzde } \\
\text { (\%) }\end{array}$ \\
\hline Çalıșmıyor & 138 & 57,5 \\
\hline Çiftçi & 2 & 0,8 \\
\hline Esnaf & 6 & 2,5 \\
\hline İş̧i (ya da ișçi emeklisi) & 36 & 15,0 \\
\hline $\begin{array}{l}\text { Memur (ya da } \\
\text { memur emeklisi) }\end{array}$ & 27 & 11,3 \\
\hline Diğer & 28 & 11,7 \\
\hline
\end{tabular}

Anne-babanın yaptıkları işin yanı sıra eğitim durumları da öğrenci ailelerine ilişkin dikkate değer bir veri sunmaktadır. Babası ilkokul ve ortaokul mezunu olan öğrencilerin oranı (yüzde 37,1) dikkate değerdir. Buna karşın öğrencilerin yüzde 60'ının babası lise (yüzde 34,2) ve üniversite $(25,8)$ mezunudur. Dolayısıyla her üç öğrenciden birinin babasının ilkokul veya ortaokul mezunu olduğu, üçte ikisinin ise lise veya üniversite mezunu olduğu kaydedilebilir.

Annelerinin eğitim durumlarına bakıldığında, yarısının ilkokul (yüzde 32,1 ) ve ortaokul (yüzde 17, 9) mezunu olduğu ortaya çıkmaktadır. Annesi lise mezunu olanların oranı yüzde 31,7, üniversite mezunu olanların oranı ise 13,3'tür. Buradan hareketle, öğrencilerin annelerinin babalarına göre daha düşük bir eğitim derecesine sahip olduğu, öğrenci annelerinde ilkokul ve ortao- 
kul düzeyinde eğitim derecesinin, babalarında ise lise ve üniversite derecesinde eğitimin ağırlıkta olduğu belirtilebilir. Yine de lise ve üniversite mezunu annelerin oranının toplamı yüzde 45'tir. Dolayısıyla öğrencilerin annelerinin eğitim durumlarında da lise ve üniversite mezuniyeti azımsanmayacak bir oranı kaplamaktadır. Bu veriler ışığında öğrencilerin eğitimli ailelerden geldikleri belirtilebilir.

Tablo 3. Öğrencilerin Babalarının Eğitim Durumu

\begin{tabular}{|l|c|c|}
\hline & Sıklık & $\begin{array}{c}\text { Yüzde } \\
(\%)\end{array}$ \\
\hline illkokul & 52 & 21,7 \\
\hline Lise & 82 & 34,2 \\
\hline Ortaokul & 37 & 15,4 \\
\hline Üniversite & 62 & 25,8 \\
\hline Diğer & 6 & 2,5 \\
\hline
\end{tabular}

Tablo 4. Öğrencilerin Annelerinin Eğitim Durumu

\begin{tabular}{|l|c|c|}
\hline & Sıklık & $\begin{array}{c}\text { Yüzde } \\
(\%)\end{array}$ \\
\hline illkokul & 77 & 32,1 \\
\hline Lise & 76 & 31,7 \\
\hline Ortaokul & 43 & 17,9 \\
\hline Üniversite & 32 & 13,3 \\
\hline Diğer & 10 & 4,2 \\
\hline
\end{tabular}

Öğrencilerin yarıya yakınının (yüzde 46,4) iki çocuklu ailelerden, yaklaşı üçte birinin (yüzde 31,4) ise üç çocuklu ailelerden geldiği görülmektedir. Yüzde 7,5'i tek çocuklu ailelerden gelirken, geri kalan kesimin (yüzde 14,7) ise 4 ve daha fazla çocuklu ailelerden geldiği söylenebilir. Öğrenci ailelerinin aylık gelirleri de öğrencilerin maddi olanaklarını ve sosyo-ekonomik profillerini belirlemede önemli bir göstergedir. Buna göre öğrenci ailelerinin yarıya yakını (yüzde 44,4) aylık 4 bin TL'nin altında bir hane gelirine sahiptir. Asgari ücret bazında ele alındığında, ailelerin yüzde $15,4^{\prime}$ ü araştırmanın yapıldığı dönemde yaklaşık asgari ücret seviyesi olan 2330 TL ve altında bir hane gelirine sahiptir. Ailelerin üçte birinden biraz fazlası (yüzde 38,8) ise $5000 \mathrm{TL}$ üzerinde bir hane gelirine ulaşabilmektedir. Ailedeki çocuk sayısı ve hane geliri birlikte düşünüldüğünde, öğrencilerin ailelerinden alabilecekleri destek ve geçim koşullarının darlığına ilişkin genel bir manzara da oluşmaktadır.

Tablo 5. Öğrenci Ailelerinin Aylık Hane Gelirleri

\begin{tabular}{|l|c|c|}
\hline & Sıklık & $\begin{array}{c}\text { Yüzde } \\
\text { (\%) }\end{array}$ \\
\hline 0-3999 TL & 95 & 44,4 \\
\hline 4000-4999 TL & 36 & 16,8 \\
\hline 5000 TL ve üzeri & 83 & 38,8 \\
\hline
\end{tabular}

Tablo 6. Öğrencilerin Bireysel

Aylık Gelirleri

\begin{tabular}{|l|c|c|}
\hline & Sıklık & $\begin{array}{c}\text { Yüzde } \\
(\%)\end{array}$ \\
\hline 0-999 TL & 125 & 58,7 \\
\hline 1000-2000 TL & 77 & 36,2 \\
\hline 2001 TL ve üzeri & 9 & 4,2 \\
\hline
\end{tabular}


Bu kapsamda öğrencilerin aylık bireysel gelirlerine bakıldığında, yaklaşık üçte birinin (yüzde 30) 500 TL ve altında bir gelirle yaşamaya çalıştığı, yüzde 28,7'sinin ise 501-1000 TL aralığında bir gelire sahip olduğu görülür. Buradan hareketle öğrencilerin büyük çoğunluğunun (yüzde 58,7) yaşamını sürdürebilmek için aylık 1000 TL'nin altında bir gelire sahip olduğu, yaklaşık üçte birinin (yüzde 36, 2) ise 1000-2000 TL arasında bir gelire ulaşabildiği görülmektedir. Öğrencilerin ortalama gelirlerinin 979 TL olduğu (mean=979) tespit edilebilir.

Öğrencilerin gelirlerini oluşturan kalemler içerisinde ailelerden alınan destekler ilk sıradadır (yüzde 66,7). Buna ek olarak burslar (yüzde 35,4), öğrenci kredileri (yüzde 32,9) ve çalışanlar için ücretler (yüzde 22) diğer gelir kaynaklarını oluşturur. ${ }^{14}$ Öğrencilerin yarısından fazlasının (yüzde 53,3) yalnızca aileden gelirlerinin olduğu, burs ya da kredi gibi gelirlerinin olmadığı görülmektedir. Üçte birinin ise (yüzde 33,3) ailesinden herhangi bir gelir desteği bulunmamakta, bu öğrenciler diğer gelir kalemleriyle (burs, kredi ya da ücret) yaşamlarını sürdürmeye çalışmaktadır.

Bu koşullarda öğrencilerin yaklaşık beşte biri (yüzde 22,1) çalıştığını belirtmiştir. Bu kesim içinde, eğitimini almakta olduğu alanla ilgili bir işte çalışanların oranı yüzde 41,5; başka herhangi bir işte çalışanların oranı ise 58,4'tür. Bununla birlikte, tüm öğrencilerin yüzde 35'i eğitimini almakta olduğu alanla ilgili bir iş aradığını, yüzde 17,5'i ise başka herhangi bir iş aradığını ifade etmiştir. Genel itibariyle bakıldığında öğrencilerin yarısından fazlası (yüzde 52,5) çalışmak üzere bir iş aradığını belirtmiş durumdadır. Bu durum, bir yandan öğrencilerin mevcut geçim durumlarını iyileştirme isteklerinin, diğer yandan ise emek piyasasına mümkün olduğunca erken girebilme ve tutunma şanslarını artırma arayışlarının bir göstergesi olarak değerlendirilebilir.

Çalışma isteğinin yanı sıra aileden alınan desteklerin varlığı da öğrencilerin tutunma arayışlarında önemli bir etkendir. Zira aile destekleri öğrencilerin (eğitimleri sürerken ya da mezun olduktan sonra) medya emek piyasasında stajyerlik adı altında ücretsiz veya çok düşük ücretlerle çalışmaya ne kadar süre dayanabileceklerini etkileyen bir unsurdur. Ailesinden gelir desteği olan öğrencilerin, mezuniyet sonrası sektörde tutunabilmek için çok daha uzun sürelerle düşük ücretlere tolerans gösterebilecekleri beklenebilir.

\section{•.•}

14 Öğrencilerin bir bölümü için birden fazla gelir kalemi söz konusu olduğundan buradaki toplamlar yüzde 100 'den fazladır. 


\section{iș Bulma Umudu ve Kanalları}

Medya emek piyasasına dair algı ve beklentilerin önemli bir boyutu iş bulma umudu ve işe giriş sürecidir. Bu kapsamda öğrencilere ilk olarak "Sizce sektörde hangi yollarla iş bulmak daha kolaydır" sorusu yöneltilmiş ve iş bulma kanallarına dönük düşünceleri tespit edilmiştir.

Tablo 7. Sizce Sektörde Hangi Yollarla İ̦ Bulmak Daha Kolaydır?

\begin{tabular}{|l|c|c|}
\hline & Sıklık & Yüzde (\%) \\
\hline Ailevi Iliș̦kiler & 25 & 10,4 \\
\hline Tanıdıklar/Eș Dost İlișkileri & 99 & 41,3 \\
\hline Meslek Örgütleri & 15 & 6,3 \\
\hline Siyasi Ilișkiler/Partiler & 53 & 22,1 \\
\hline Stajyerlik & 41 & 17,1 \\
\hline Diğer & 7 & 2,9 \\
\hline
\end{tabular}

Tablo 7'den de görüleceği üzere öğrenciler, medya emek piyasasında iş bulmanın en kolay "Tanıdıklar/Eş Dost ilişkileri" sayesinde gerçekleştiğini düşünmektedir. İkinci sırada gelen yanıt ise dikkate değerdir. Öğrencilerin beşte birinden daha fazlası (yüzde 22,1) sektörde iş bulabilmenin "Siyasi ilişkiler/partiler" aracilığıyla daha kolay olduğunu ifade etmiştir. Makalenin ikinci bölümünde de tartısııldığı gibi, medya sektörünün son yıllarda iktidarla girdiği yakın ilişkiler göz önünde bulundurulduğunda, öğrencilerde "siyasi ilişkiler ve partiler" in etkinliğine dönük bir algının ortaya çıkmış olması şaşırtıcı olmamaktadır. Bir diğer dikkat çeken sonuç meslek örgütlerine ilişkindir. Meslek örgütleri kanalıyla iş bulabilme beklentisi öğrenciler nezdinde oldukça düşüktür. Bu durumun meslek örgütlerinin sektördeki etkisinin zayıfllğ ${ }^{15}$ ile paralellik taşıdığı söylenebilir. Bu soruya verilen yanıtlar, örneklemdeki üniversiteler bazında anlamlı bir farklılık göstermemektedir $(\mathrm{t}=-1,417, \mathrm{p}=0,158)$.

İş bulma kanallarının yanı sıra iş bulma umudu da öğrencilerin emek piyasasına dönük beklentileri için önemli bir göstergedir. Bu kapsamda öğrencilere "Mezun olunca çok zorlanmadan beklentilerime uygun bir iş bulabileceğime inanıyorum" cümlesine dönük yaklaşımları sorulmuştur.

15 Meslek örgütlerinin medya endüstrisinde etkinliğinin giderek zayıflamış olması pek çok boyutta kendini göstermektedir. Bunlar arasında mesleği düzenleyen politika yapım süreçleri ve kurullarda meslek örgütlerine yeterince yer verilmemesi, bu örgütlerin yaptırım güçlerinin neredeyse kalmamış olması ve üye sayılarının düşüklüğü gibi etkenler sayılabilir. 
Tablo 8. "Mezun olunca çok zorlanmadan beklentilerime uygun bir iș bulabileceğime inanıyorum"

\begin{tabular}{|l|c|c|}
\hline & Sıklık & Yüzde (\%) \\
\hline Kesinlikle Katılıyorum & 5 & 2,1 \\
\hline Katılıyorum & 33 & 13,8 \\
\hline Kararsızım & 80 & 33,5 \\
\hline Katılmıyorum & 80 & 33,5 \\
\hline Kesinlikle Katılmıyorum & 41 & 17,2 \\
\hline
\end{tabular}

Öğrencilerin yalnızca yüzde 15,9'u beklentilerine uygun bir iş bulabileceği kanaatine sahipken, üçte biri (yüzde 33,5) bu konuda kararsız olduğunu ifade etmiştir. Yarısından fazlası (yüzde 50,7) ise mezun olduktan sonra beklentilerine uygun bir iş bulabileceği umudunu taşımamaktadır. İş bulabilme beklentisine dönük bu kanaatlerin cinsiyete, öğrencinin gelir düzeyine, bölümüne ve sınıfına göre anlamlı bir farklılık göstermediği tespit edilmiştir. Dolayisiyla, her cinsiyetten $(t=0,488, p=0,628)$ ve gelir düzeyinden $(F=0,189$, $\mathrm{p}=0,828)$, her bölüm $(\mathrm{F}=0,993, \mathrm{p}=0,372)$ ve sinıftan $(\mathrm{F}=2,068, \mathrm{p}=0,105)$ öğrenci, beklentilerine uygun iş bulma umuduna dönük kanaatlerinde benzeşmektedir. Öğrencilerin "Bu sektörde iş bulmak çok zor" cümlesine dönük ifadeleri de bu durumu destekler niteliktedir.

Tablo 9. "Bu sektörde iș bulmak çok zor"

\begin{tabular}{|l|c|c|}
\hline & Sıklık & Yüzde (\%) \\
\hline Kesinlikle Katılıyorum & 96 & 40,3 \\
\hline Katılıyorum & 73 & 30,7 \\
\hline Kararsızım & 40 & 16,8 \\
\hline Katılmıyorum & 25 & 10,5 \\
\hline Kesinlikle Katılmıyorum & 4 & 1,7 \\
\hline
\end{tabular}

Öğrencilerin yüzde 12,2'si bu görüşe katılmamakta, buna karşın büyük çoğunluğu (yüzde 71,0) medya sektöründe iş bulmanın çok zor olduğunu düşünmektedir. "Mezun olunca çok zorlanmadan beklentilerime uygun bir iş bulabileceğime inanıyorum" ifadesi ile "Bu sektörde iş bulmak çok zor" ifadesi arasındaki ilişki incelendiğinde, her ikisi arasında istatistiksel olarak anlamlı ve negatif yönlü bir ilişki olduğu $(r=-0,370, p=0,000)$ tespit edilmiştir. Öğrencilerin sektörde iş bulmanın zorluğuna dönük kanaatleri arttıkça, beklentilerine uygun bir iş bulabilme umutları azalmaktadır. 
İş bulabilme konusundaki bu umutsuzluk hali, önceki bölümlerde değinilen yüksek işsizlik rakamlarıyla birlikte düşünüldüğünde daha da anlamlı hale gelmektedir. Öğrencilerin bir yandan ülkedeki genel durumla ilişkili olarak, diğer yandan ise kendi alanlarındaki yüksek işsizliğe paralel şekilde umutlarını kaybetmekte oldukları düşünülebilir. Üniversite eğitimi almakta olan öğrencilerin içinde bulunduğu bu durumun, hem gençlerdeki toplumsal-bireysel etkiler bağlamında hem de iletişim eğitimine dönük politikalar bağlamında üzerinde durulması gereken bir konu olduğu vurgulanabilir.

Buna karşın öğrencilerde kendi alanlarında çalışmaya yönelik bir istek ve "ne iş olsa yaparım" tavrına dönük önemli bir karşı çıkış olduğu da belirtilmelidir. "Mezun olduğum alanda çalışmam şart değil, iş bulayım yeterli" yargısına dönük ifadeler bu konuda dikkate değerdir.

Tablo 10. "Mezun olduğum alanda çalıșmam șart değil, iș bulayım yeterli"

\begin{tabular}{|l|c|c|}
\hline & Sıklık & Yüzde (\%) \\
\hline Kesinlikle Katılıyorum & 13 & 5,5 \\
\hline Katılıyorum & 28 & 11,8 \\
\hline Kararsızım & 59 & 24,9 \\
\hline Katılmıyorum & 77 & 32,5 \\
\hline Kesinlikle Katılmıyorum & 60 & 25,3 \\
\hline
\end{tabular}

Öğrencilerin sektörde iş bulmanın zorluğu konusunda ağırlıklı olarak geliştirdikleri görüş bu yargi ifadesi için geçerli değildir. "İş bulayım yeterli" şeklinde kanaat belirtenlerin oranı yalnızca 17,3'tür. Buna karşın öğrencilerin dörtte biri (yüzde 24,9) kararsız olduğunu ifade etmiş, yarısından fazlası $(57,8)$ ise bu görüşe katılmadı̆̆ını belirtmiştir. Yanıtlar cinsiyet temelinde incelendiğinde anlamlı bir farklılık oluşmadığ $(t=1,592, p=0,113)$ görülmektedir. Buna karşın üniversite bazında incelendiğinde örneklemdeki iki üniversite arasında anlamlı bir fark olduğu $(t=2,423, p=0,016)$ tespit edilmiş, Ankara Üniversitesi'ndeki öğrencilerin bu yargıya katılmama oranlarının Hacı Bayram Veli Üniversitesi'ndeki öğrencilere göre daha fazla olduğu bulgulanmıştır. Genel olarak bakıldığında iletişim öğrencilerinin sektörün tüm zorluklarına karşın kendi mesleklerini icra etmek ve aldıkları eğitimle bağlantılı alanlarda bir yaşam pratiği geliştirmek istedikleri söylenebilir.

\section{Çalıșma Koșulları ve Ortamı}

Medya emek piyasasına dönük alg1 ve beklentilerin önemli bir boyutu, öğrencilerin çalışma koşulları ve ortamına dönük değerlendirmeleridir. Öğrencilere öncelikle, mesleğe başladıklarında en çok sıkıntı çekeceklerini düşündükleri 
en önemli iki konu sorulmuştur. Düşük ücretler (144 kişi) ve çok yoğun çalıştırılma (67 kişi) en çok işaret edilen sorun alanları olmuştur. Bunları işten çıkarılma (66 kişi) ve çalıştığı kurumun uygulamaları nedeniyle mesleği layıkıyla yapamama (57 kişi) seçenekleri takip etmektedir. ${ }^{16}$ Öğrencilerin, medya emek piyasasındaki koşullara dönük bir farkındalığa sahip oldukları ve beklentilerinin bu çerçevede geliştiği söylenebilir. "Sektörde ücretler yeterince iyidir" ve "Sektörde çalışma koşulları çok kötü" yargılarına dönük ifadeleri de bu durumu destekler niteliktedir.

Tablo 11. "Sektörde ücretler yeterince iyidir"

\begin{tabular}{|l|c|c|}
\hline & Sıklık & $\begin{array}{c}\text { Yüzde } \\
(\%)\end{array}$ \\
\hline Kesinlikle Katılıyorum & 5 & 2,1 \\
\hline Katılıyorum & 11 & 4,6 \\
\hline Kararsızım & 92 & 38,8 \\
\hline Katılmıyorum & 70 & 29,5 \\
\hline $\begin{array}{l}\text { Kesinlikle } \\
\text { Katılmıyorum }\end{array}$ & 59 & 24,9 \\
\hline
\end{tabular}

Tablo 12. "Sektörde çalıșma koșulları çok kötü"

\begin{tabular}{|l|c|c|}
\hline & Sıklık & $\begin{array}{c}\text { Yüzde } \\
(\%)\end{array}$ \\
\hline Kesinlikle Katılıyorum & 51 & 21,4 \\
\hline Katılıyorum & 77 & 32,4 \\
\hline Kararsızım & 86 & 36,1 \\
\hline Katılmıyorum & 23 & 9,7 \\
\hline $\begin{array}{l}\text { Kesinlikle } \\
\text { Katılmıyorum }\end{array}$ & 1 & 0,4 \\
\hline
\end{tabular}

Tablolardan takip edilebileceği üzere öğrencilerin üçte birinden fazlası (yüzde 38,8) ücretler konusunda kararsız olduğunu belirtirken, yarısından fazlası (yüzde 54,4) ücretlerin yeterli düzeyde olmadığını ifade etmektedir. Çalışma koşullarına dönük kanaatleri de ücretler konusundaki yaklaşımlarına benzer şekilde ortaya çıkmaktadır. Öğrencilerin yine yarısından fazlası (yüzde 53,8) medya piyasasında çalışma koşullarının çok kötü olduğunu düşünmektedir. Ücretlere ve çalışma koşullarına dönük bu değerlendirmeler cinsiyete $(\mathrm{t}=-0,099, \mathrm{p}=0,921 ; \mathrm{t}=0,374, \mathrm{p}=0,709)$ göre anlamlı bir farklılık göstermemekle birlikte, bölümlere ve üniversitelere göre bir farklılık tespit edilebilmektedir.

Ücretler konusunda en belirgin farklılık Halkla İlişkiler ve Tanıtım ile Gazetecilik bölümleri arasında ortaya çıkmaktadır. Halkla İlişkiler ve Tanıtım bölümü öğrencilerinin sektörde ücretlerin iyi olduğuna dönük kanaatleri Gazetecilik öğrencilerine göre daha yüksektir ( $F=7,353$, p=0,001). Gazetecilik ve Halkla İlişkiler bölümleri arasında ortaya çıkan anlamlı farklılık çalışma koşullarına dönük değerlendirmelerde de kendini göstermektedir $(F=6,559$, -..

$16 \mathrm{Bu}$ soruda çoklu yanıt seçeneği uygulandığından oran yerine kişi sayısı verilmiştir ve toplamlar $\mathrm{N}=240$ 'tan fazladır. 
$p=0,002)$. Gazetecilik öğrencilerinin çalışma koşullarının kötülüğüne dönük kanaatleri Halkla İlişkiler öğrencilerininkine göre daha fazladır. Çalışma koşulları konusunda üniversite bazında da anlamlı bir farklılık tespit edilmektedir ( $\mathrm{t}=-3,540, \mathrm{p}=0,000)$. Sektörde çalışma koşullarının kötü olduğuna ilişkin kanaatlerin Ankara Üniversitesi öğrencilerinde daha yüksek olduğu belirtilebilir.

Çalışma koşulları ve ortamına dönük bir diğer unsur, sektörde geçerli olan donanım ve becerilerdir. Öğrencilerin üçte ikisinden fazlası (yüzde 68,9) çalışma ortamında entelektüel donanımdan daha çok teknik becerilerin geçerli olduğu yönünde görüş bildirmiştir. Kararsıların oranı yüzde 22,3 iken, bu görüşe katılmayan öğrencilerin oranı yüzde 8,8'dir.

Tablo 13. "Sektörde entelektüel donanımdan daha çok teknik beceriler geçerlidir"

\begin{tabular}{|l|c|c|}
\hline & Sıklık & Yüzde (\%) \\
\hline Kesinlikle Katılıyorum & 71 & 29,8 \\
\hline Katılıyorum & 93 & 39,1 \\
\hline Kararsızım & 53 & 22,3 \\
\hline Katılmıyorum & 17 & 7,1 \\
\hline Kesinlikle Katılmıyorum & 4 & 1,7 \\
\hline
\end{tabular}

Günümüzde entelektüel donanımın sektörde geri planda kaldığ1 ve teknik becerilerin ön plana çıktığı, hatta medya çalışanlarının vasıflarının salt teknik becerilerle sınırlandırıldığı sıklıkla vurgulanan bir konudur. Medya gibi sembolik üretim yapan ve toplumsal bilgi, tutum, fikir ve görüşlerin oluşturulmasında merkezi konumda olan bir endüstride çalışmak üzere yetiştirilen öğrencilerin sektörün bu eğilimlerine dönük farkındalıkları önemlidir. Buna karşın öğrenciler, mesleğin niteliğini artırmak için entelektüel donanımın gerekli olduğu konusunda neredeyse görüş birliği içindedirler (yüzde 85,3).

Tablo 14. "Mesleğin niteliğini artırmak için entelektüel donanım gereklidir"

\begin{tabular}{|l|c|c|}
\hline & Sıklık & Yüzde (\%) \\
\hline Kesinlikle Katılıyorum & 100 & 42,0 \\
\hline Katılıyorum & 103 & 43,3 \\
\hline Kararsızım & 24 & 10,1 \\
\hline Katılmıyorum & 9 & 3,8 \\
\hline Kesinlikle Katılmıyorum & 2 & 0,8 \\
\hline
\end{tabular}


Buradan hareketle öğrencilerin, mesleğin vasıflarının teknik becerilerin yanında entelektüel donanımla da şekillenmesi gerektiğini düşündüğü fakat sektördeki teknik beceri beklentisinin onları bu yönde sınırlandırdığı düşünülebilir.

\section{Mesleğin Anlamı ve Toplumsal Yararı}

Öğrencilerin emek piyasasına dönük alg1 ve beklentilerini şekillendiren önemli bir unsur eğitimini aldıkları mesleğe, onun toplumsal saygınlığına ve yararına dönük değerlendirmeleridir. Bu kapsamda öğrencilere öncelikle, okudukları bölümü tercih etmelerinin en önemli nedeni sorulmuştur. Öğrencilerin yarısından çoğu (yüzde 55,8) mesleğe duyduğu ilgi nedeniyle bölümünü seçtiğini belirtirken, ikinci sırada gelen yanıt "puanımın bu bölüme yetmesi" olmuştur (yüzde 17,5). Dolayısıyla öğrencilerin büyük çoğunluğunun iletişim fakültesine kendi ilgi ve isteği ile geldiği belirtilebilir. Buna karşın “İletişim fakültesi mezunu olmanın değersizleştiğini düşünüyor musunuz?” sorusuna verilen yanıtlar dikkate değerdir.

Tablo 15. Illetișim fakültesi mezunu olmanın değersizleștiğini düșünüyor musunuz?

\begin{tabular}{|l|c|c|}
\hline & Sıklık & Yüzde (\%) \\
\hline Evet & 178 & 74,2 \\
\hline Hayır & 62 & 25,8 \\
\hline
\end{tabular}

Öğrencilerin yaklaşık dörtte biri (yüzde 25,8) bu fikre sahip değilken, dörtte üçü (yüzde 74,2) iletişim fakültesi mezunu olmanın değersizleştiğini belirtmiştir. Bu veri, medya sektöründe uzun süredir yaşanan güvencesizleşme ve değersizleşme süreçlerinin iletişim fakültesi öğrencilerinde de bu yönde bir kanaat oluşturduğunu göstermesi bakımından önemlidir. Değersizleşme kanaatinin öğrencilerin cinsiyeti, sınıfı ve bölümü açısından bir farklılık taşıyıp taşımadığı incelendiğinde, cinsiyet $(t=0,360, p=0,719)$ ve sınıflar $(\mathrm{F}=0,488, \mathrm{p}=0,691)$ temelinde anlamlı bir farklılığın bulunmadığı fakat bölümler düzeyinde bir farklılık oluştuğu tespit edilmiştir $(F=4,711, p=0,010)$. Buna göre iletişim fakültesi mezunu olmanın değersizleştiği yönündeki kanaatler Radyo-Televizyon ve Sinema bölümü öğrencilerinde daha yüksektir.

Buna karşın öğrencilerin yaklaşık üçte biri (yüzde 32,6) mesleği yapabilmek için eğitim almanın gerekli olmadığını belirtirken, yarısından çoğu (yüzde 51,4) bu alanda çalışabilmek için eğitim almanın gerektiğini ifade etmiştir. 
Tablo 16. "Okuduğum mesleği yapabilmek için eğitim almak gerekli değil"

\begin{tabular}{|l|c|c|}
\hline & Sıklık & Yüzde (\%) \\
\hline Kesinlikle Katılıyorum & 34 & 14,2 \\
\hline Katılıyorum & 44 & 18,4 \\
\hline Kararsızım & 38 & 15,9 \\
\hline Katılmıyorum & 73 & 30,5 \\
\hline Kesinlikle Katılmıyorum & 50 & 20,9 \\
\hline
\end{tabular}

Bu yaklaşım, cinsiyet $(t=0,394, p=0,694)$, sınıf $(F=0,715, p=0,544)$, bölüm $(\mathrm{F}=0,986, \mathrm{p}=0,374)$ ve üniversiteler $(\mathrm{t}=0,607, \mathrm{p}=0,544)$ bazında anlamlı bir farklılık göstermemektedir. Öğrencilerin bu kanaatleri, mesleğin eğitim gerektiren özel bir faaliyet alanı olduğu ve herkes tarafından yapılamayacağına dönük sınır çizici bir yaklaşımın göstergesi olarak değerlendirilebilir. Dolayısıyla değersizleşme eğilimine karşı öğrenciler nezdinde mesleklerini savunmaya dönük bir refleksin var olduğu düşünülebilir. Zira "İletişim fakültesinde okuyarak bir meslek sahibi olacağınızı düşünüyor musunuz?" sorusuna verilen yanıtlar bu yargıyı destekler niteliktedir. Öğrencilerin üçte birinden fazlası (yüzde 37,1) "Evet", yarıya yakını (yüzde 44,2) ise "Kısmen" yanitını vermiştir. Öğrencilerin beşte birinden daha azı (yüzde 18,8) bu soruda olumsuz görüş bildirmiştir. Buradan hareketle öğrencilerin çoğunda aldıkları eğitimle mezun olduktan sonra bir meslek sahibi olacakları inancının bulunduğu söylenebilir.

Bu noktada, "İletişim fakültesinde okuyarak bir meslek sahibi olacağ1nızı düşünüyor musunuz?" ile "İletişim fakültesi mezunu olmanın değersizleştiğini düşünüyor musunuz?" soruları ilişkilendirildiğinde, her iki soruya verilen yanıtlar arasında istatistiksel olarak anlamlı ve negatif yönlü bir ilişki olduğu $(r=-0,216, p=0,000)$ tespit edilmiştir. İletişim fakültesi mezunu olmanın değersizleştiği düşüncesi arttıkça, fakülteden mezun olarak meslek sahibi olunacağına yönelik inanç azalmaktadır. Bu durum, yukarıda incelenen iş bulma konusundaki düşük beklenti ile karşılaştırıldığında, öğrencilerin mezuniyetleri sonrasındaki geleceklerini meslek sahibi işsizler ya da eksik istihdamdaki (aldıkları eğitim düzeyinin altında vasıf gerektiren işlerde istihdam edilen) üniversite mezunları olarak gördükleri söylenebilir. Bu yaklaşım, ikinci bölümde değinilen iletişim alanındaki yüksek işsizlik oranlarıyla birlikte düşünüldüğünde, öğrencilerin bu kanaatlerinin temelsiz olmadığı belirtilebilir. 
Bu konudaki bir diğer gösterge öğrencilerin, eğitimini aldıkları işin toplumdaki saygınlığı ve toplumsal faydasına dönük fikirleridir.

Tablo 17. "Eğitimini aldığım alanda yapacağım ișin toplumda saygınlık göreceğini düșünüyorum"

\begin{tabular}{|l|c|c|}
\hline & Sıklık & Yüzde (\%) \\
\hline Kesinlikle Katılıyorum & 32 & 13,5 \\
\hline Katılıyorum & 79 & 33,3 \\
\hline Kararsızım & 80 & 33,8 \\
\hline Katılmıyorum & 31 & 13,1 \\
\hline Kesinlikle Katılmıyorum & 15 & 6,3 \\
\hline
\end{tabular}

Tablo 18. "Eğitimini aldığım alanda yapacağım ișin topluma fayda sağlayacağını düșünüyorum"

\begin{tabular}{|l|c|c|}
\hline & Sıklık & Yüzde (\%) \\
\hline Kesinlikle Katılıyorum & 88 & 37,1 \\
\hline Katılıyorum & 96 & 40,5 \\
\hline Kararsızım & 37 & 15,6 \\
\hline Katılmıyorum & 8 & 3,4 \\
\hline Kesinlikle Katılmıyorum & 8 & 3,4 \\
\hline
\end{tabular}

Öğrencilerin yarıya yakını (yüzde 46,8) yapacakları işin toplumda saygınlık göreceğini, çok daha büyük çoğunluğu (yüzde 77,6$)$ ise yapacakları işin topluma fayda sağlayacağını düşünmektedir. Aradaki farktan da anlaşılacağı üzere, toplumsal faydası olan bir iş yapacağını fakat bu işin topumda yeterince saygınlık görmeyeceğini düşünen ya da bu konuda kararsız kalan öğrenci sayısı oldukça yüksektir (yüzde 30,8). Saygınlık görme konusunda cinsiyete $(t=0,058, p=0,954)$, sinıfa $(F=1,858, p=0,137)$ ve bölümlere $(F=0,810, p=0,446)$ göre anlamlı bir farklılık bulunmamakla birlikte üniversiteler arasında bir farklılık tespit edilebilmektedir $(t=2,478, p=0,014)$. Yapacakları işin toplumda saygınlık göreceği konusundaki kanaatler Ankara Üniversitesi öğrencilerinde daha yüksekken, Hacı Bayram Veli Üniversitesi öğrencilerinde daha düşüktür. Toplumsal faydaya dönük görüşler incelendiğinde de cinsiyete, sınıfa, bölüme ve üniversiteye göre anlamlı bir farklılık tespit edilmemektedir. Saygınlık görme ve toplumsal fayda konularına dönük görüşler ilişkilendirildiğinde 
ise, her iki değişken arasında anlamlı ve pozitif yönlü bir ilişki bulunduğu $(\mathrm{r}=0,428, \mathrm{p}=0,000)$, birinin arttığ1 durumlarda diğerinin de arttığ1 görülmektedir.

Dolayısıyla öğrencilerin, iletişim fakültesi eğitimi alarak topluma fayda sağlayacak ve saygı görecek bir meslek edineceklerini düşündükleri belirtilebilir. Buna karşın yanıtlarda kendini gösteren toplumsal fayda ve toplumsal saygınlık arasındaki oransal fark düşünülmeye değerdir. Bu noktada öğrencilerin, yapacakları işe değer verdikleri fakat bunun toplumdaki karşılığının yeteri derecede olmayacağına inandıkları söylenebilir.

\section{Eğitim Süreci ve Eğitim-İstihdam İlișkisi}

Medya emek piyasasına dönük algı ve beklentilerin bir diğer unsuru, üniversite eğitimine ve bunun sektörle ilişkisine yönelik düşüncelerdir. Bu kapsamda öğrencilere ilk olarak iletişim fakültesi eğitiminin hangi alanlarda yoğunlaşması gerektiğine dönük fikirleri sorulmuştur. Uygulamalı eğitim (200 kişi) ve yabancı dil eğitimi (106 kişi) en çok işaret edilen konular olmuştur. Bunları teorik donanım (65 kişi) ve genel kültür (43 kişi) seçenekleri takip etmektedir. ${ }^{17} \mathrm{Bu}$ durum eğitimleri sırasında öğrencilerin kendilerini en eksik hissettikleri alanlarla paralellik taşımaktadır.

Tablo 19. Eğitiminiz sırasında kendinizi en eksik hissettiğiniz alan hangisidir?

\begin{tabular}{|l|c|c|}
\hline & Sıklık & Yüzde (\%) \\
\hline Teorik Donanım & 14 & 5,9 \\
\hline Uygulamalı Eğitim & 122 & 51,0 \\
\hline Yabancı Dil Eğitimi & 95 & 39,7 \\
\hline Genel Kültür & 7 & 2,9 \\
\hline Diğer & 1 & 0,4 \\
\hline
\end{tabular}

Öğrencilerin yarısından çoğu (yüzde 51,0) kendilerini en eksik hissettikleri alanın uygulamalı eğitim olduğunu belirtirken, üçte birinden fazlası (yüzde 39,7) yabancı dil eğitimi konusunda eksik hissettiğini ifade etmiştir. Bu iki alan öğrencilerin yüzde 90'lık bir oranını kaplamakta ve eğitim konusundaki beklentilerin uygulama ve yabancı dil ekseninde şekillendiğini işaret etmektedir. Bu durum, ilk bölümde tartışılan eğitim-istihdam ilişkisinin günümüz -・・

17 Bu soruda çoklu yanıt seçeneği uygulandığından oran yerine kişi sayısı verilmiştir ve toplamlar $\mathrm{N}=240^{\prime} \tan$ fazladır. 
koşullarındaki niteliğine de işaret etmektedir. Öğrencilerin eğitimden beklentilerinin çoğunlukla piyasanın gereklerine göre şekillendiği söylenebilir.

Bu durum staj konusunda da kendini göstermektedir. Öğrencilerin yaklaşık üçte biri (yüzde 36,0) staj deneyimine sahip olduğunu ifade ederken, yaklaşık üçte ikisi (yüzde 64,0) şu ana kadar herhangi bir staj deneyiminin olmadığını belirtmiştir. Staj deneyimi üniversite düzeyinde incelendiğinde anlamlı bir farklılık görülmemekle $(\mathrm{t}=1,396, \mathrm{p}=0,164)$ birlikte cinsiyet $(\mathrm{t}=-2,241$, $\mathrm{p}=0,026)$, sinıf $(\mathrm{F}=9,777, \mathrm{p}=0,000)$ ve bölüm $(\mathrm{F}=5,509, \mathrm{p}=0,005)$ düzeyinde anlamlı farklılıklar bulunmaktadır. Staj yapma konusunda kadın öğrencilerin oranı erkeklerden daha yüksektir. Sınıflar düzeyinde, beklenebileceği gibi 3. ve 4. sınıftaki öğrencilerin staj yapma oranları daha fazladır. Bölümler arasında ise Gazetecilik bölümü öğrencilerinin staj deneyiminin diğer bölümlere göre daha fazla olduğu, en az staj deneyiminin ise Halkla İlişkiler bölümünde olduğu saptanmıştır.

Bu sonuçlar yalnızca öğrencilerin isteksizliği ya da eksikliği ile açılanamayacağı gibi buradaki büyük payın esasen sektörde öğrenciler için yeterli düzeyde staj imkanı bulunamamasıyla ilişkili olduğu söylenebilir. Bu nedenle öğrencilerin büyük çoğunluğu (yüzde 80,7) eğitimleri süresince stajın zorunlu olması gerektiğini ifade etmiştir.

Tablo 20. "Öğrenim süresi içinde stajın zorunlu olması gerektiğini düșünüyorum"

\begin{tabular}{|l|c|c|}
\hline & Sıklık & Yüzde (\%) \\
\hline Kesinlikle Katılıyorum & 133 & 55,6 \\
\hline Katılıyorum & 60 & 25,1 \\
\hline Kararsızım & 25 & 10,5 \\
\hline Katılmıyorum & 13 & 5,4 \\
\hline Kesinlikle Katılmıyorum & 8 & 3,3 \\
\hline
\end{tabular}

Öğrencilerin, zorunlu staj yoluyla herkes için staj imkanı sağlanacağına inanıyor oldukları düşünülebilir. Bu nokta önemlidir, çünkü staj yapmak öğrenciler açısından sektörle tanışmanın ve meslek pratiği edinmenin önemli kanallarından biridir. Öğrencilerin çoğu (yüzde 81,9), staj yapmanın iş bulmalarını kolaylaştıracağına inanmaktadır. Zorunlu staj isteğinin bu durumla bağlantısı olduğu belirtilebilir. 
Tablo 21. "Staj yapmanın iș bulmamı kolaylaștıracağına inanıyorum"

\begin{tabular}{|l|c|c|}
\hline & Sıklık & Yüzde (\%) \\
\hline Kesinlikle Katılıyorum & 91 & 38,2 \\
\hline Katılıyorum & 104 & 43,7 \\
\hline Kararsızım & 29 & 12,2 \\
\hline Katılmıyorum & 10 & 4,2 \\
\hline Kesinlikle Katılmıyorum & 4 & 1,7 \\
\hline
\end{tabular}

$\mathrm{Bu}$ noktada öğrencilerin fakülte eğitimleri dışında herhangi bir sertifika ya da eğitim programına katılıp katılmadıkları incelenmiştir. Öğrencilerin yaklaşık üçte biri (yüzde 37,1) mesleki bilgi ve becerilerini artırmak için fakülte eğitimi haricinde herhangi bir sertifika/eğitim programına katıldığını belirtirken, yaklaşık üçte ikisi (yüzde 62,9) böyle bir programa katılmadığı$\mathrm{n}$ ifade etmiştir. Böylesi programlara katılım konusunda cinsiyet $(\mathrm{t}=-2,044$, $\mathrm{p}=0,042)$ ve sinıf $(\mathrm{F}=4,421, \mathrm{p}=0,005)$ düzeyinde anlamlı bir farklılık tespit edilmektedir. Katılanlar içindeki cinsiyet ve sınıf dağılımları çapraz tablolar şeklinde incelendiğinde çoğunluğunun 3. (yüzde 37,1) ve 4. (yüzde 24,7) s1nıflardan oluştuğu ve böylesi programlara katılanların yarısından çoğunun (yüzde 57,3) kadın öğrenciler olduğu görülmektedir. Dolayısıyla mezuniyete yaklaştıkça fakülte dışı programlara katılma oranının arttığı ve bu eğilimin kadın öğrencilerde daha fazla olduğu söylenebilir. Benzer bir farklılık üniversiteler bazında da tespit edilmektedir. Fakülte harici bir sertifika/eğitim programına katılan öğrencilerin yarısından çoğunun (yüzde 57,3) Hacı Bayram Veli Üniversitesi'nden olduğu belirtilebilir. Bölümler bazında ise anlamlı bir farklılık bulunmamaktadır $(\mathrm{F}=0,230, \mathrm{p}=0,795)$.

Öğrencilerin medya emek piyasasına dönük algı ve beklentilerini etkileyen bir diğer unsur üniversite eğitimine dönük değerlendirmeleridir. Üniversite eğitiminin öğrencileri iş/meslek yaşamına gerektiği gibi hazırlayıp hazırlamadığı konusunda öğrenciler üç farklı görüşe bölünmüş görünmektedir. Üçte biri (yüzde 32,7) eğitimin onları iş/meslek yaşamına gerektiği gibi hazırlamadığını ifade ederken, üçte birinden daha azı (yüzde 29,3) bu konuda olumlu görüş bildirmektedir. Üçte birinden fazlası (yüzde 38,1) ise kararsız olduğunu söylemiştir. 
Tablo 22. "Üniversitede aldığım eğitimin beni iș/meslek yașamına gerektiği gibi hazırladığına inanıyorum"

\begin{tabular}{|l|c|c|}
\hline & Sıklık & Yüzde (\%) \\
\hline Kesinlikle Katılıyorum & 22 & 9,2 \\
\hline Katılıyorum & 48 & 20,1 \\
\hline Kararsızım & 91 & 38,1 \\
\hline Katılmıyorum & 53 & 22,2 \\
\hline Kesinlikle Katılmıyorum & 25 & 10,5 \\
\hline
\end{tabular}

Bu görüşlerin cinsiyet, bölüm, sinıf ve üniversite düzeyinde bir farkl1lık gösterip göstermediği incelendiğinde, cinsiyet $(t=-0,162, p=0,871)$ ve bölümlere $(F=2,100, p=0,125)$ göre bir farklılığın ortaya çıkmadığı fakat sınıflar $(\mathrm{F}=3,654, \mathrm{p}=0,013)$ ve üniversite $(\mathrm{t}=-3,175, \mathrm{p}=0,002)$ düzeyinde anlamlı farkl1lıklar bulunduğu tespit edilmiştir. Üniversite eğitiminin kendilerini iş / meslek yaşamına gerektiği gibi hazırladığı konusundaki görüşler 1. sınıf öğrencilerinde daha fazlayken, bu konudaki olumsuz görüşler son sınıf öğrencilerinde daha yüksektir. Bu durum 1. sınıf öğrencilerinde üniversite eğitimine dönük beklentilerin ve umutların yüksekliği ile ilişkilendirilebilir. Dolayısıyla okulda geçirilen zaman artıp mezuniyet yaklaştıkça iş bulma kaygısının arttığı ve öğrencilerin üniversite eğitimine dönük görüşlerinin değiştiği düşünülebilir. Üniversiteler arasında da bu konuda anlamlı bir farklılık bulunmaktadır. Aldıkları eğitimin kendilerini iş / meslek yaşamına gerektiği gibi hazırladığına ilişkin olumlu kanaatler Ankara Üniversitesi öğrencilerinde daha yüksektir.

Benzer bir durum öğrencilerin fakültelerinde nitelikli eğitim alıp almadıklarına dönük görüşlerinde de kendini göstermektedir. Öğrencilerin yarısı (yüzde 49,6) okudukları fakültelerde nitelikli eğitim aldığını düşünürken, yaklaşık üçte biri (yüzde 30,9) bu konuda kararsızlığını ifade etmiştir. Nitelikli eğitim alamadığını düşünenlerin oranı ise yüzde 19,5’tir.

Tablo 23. "Okuduğum üniversitede nitelikli eğitim aldığımı düșünüyorum"

\begin{tabular}{|l|c|c|}
\hline & Sıklık & Yüzde (\%) \\
\hline Kesinlikle Katılıyorum & 37 & 15,7 \\
\hline Katılıyorum & 80 & 33,9 \\
\hline Kararsızım & 73 & 30,9 \\
\hline Katılmıyorum & 32 & 13,6 \\
\hline Kesinlikle Katılmıyorum & 14 & 5,9 \\
\hline
\end{tabular}


Bu sonuçlar cinsiyet $(t=-0,333, p=0,739)$ ve sinıf $(F=0,431, p=0,731)$ temelinde anlamlı bir farklılık göstermezken, bölüm $(\mathrm{F}=7,552, \mathrm{p}=0,001)$ ve üniversiteler ( $t=7,104, \mathrm{p}=0,000)$ düzeyinde farklılıklar taşımaktadır. Okuduğu üniversitede nitelikli eğitim aldığına dönük görüşler Gazetecilik bölümü öğrencilerinde daha yüksekken, olumsuz görüşler ise en çok Radyo-Televizyon ve Sinema bölümü öğrencilerinde görülmektedir. Üniversiteler arasında ise nitelikli eğitim aldıklarına dönük kanaatler Ankara Üniversitesi öğrencilerinde daha yüksekken, Hacı Bayram Veli Üniversitesi öğrencilerinde daha düşüktür.

Öğrencilerin nitelikli eğitim aldıklarına dönük kanaatleri ile üniversite eğitiminin kendilerini iş / meslek yaşamına hazırladığına ilişkin görüşleri arasında anlamlı ve pozitif yönlü bir ilişki $(\mathrm{r}=0,414, \mathrm{p}=0,000)$ tespit edilmektedir. Nitelikli eğitim aldıkları yönündeki düşünceleri arttıkça, üniversite eğitiminin kendilerini iş/meslek yaşamına hazırladığına dönük kanaatleri de artmaktadır. Benzer şekilde öğrencilerin nitelikli eğitime yönelik görüşleri ile yapacakları işin topluma fayda sağlayacağına ilişkin kanaatleri arasında da anlamlı ve pozitif yönlü bir ilişki $(r=0,204, p=0,001)$ saptanmaktadır. Dolayısıyla genel olarak bakıldığında, öğrencilerin girdikleri eğitim sürecine ve aldıkları eğitimin niteliğine dönük görüşlerinin, emek piyasasına dönük algı ve beklentilerini şekillendirmede etkisi olduğu ifade edilebilir.

\section{Sonuç}

İletişim fakültesi öğrencilerinin medya emek piyasasına dönük algı ve beklentileri genç neslin yalnızca kendi meslek pratiklerine ve geleceklerine dönük değerlendirmelerini değil, aynı zamanda mevcut toplumsal yapının geneline ilişkin ipuçlarını da barındırmaktadır. Medya emek piyasasına dönük algı ve beklentiler, günümüzde medyanın toplumsal işlevi, medya endüstrisinin yapısı, iletişim eğitiminin sınırları ve medyada çalışma ilişkileri gibi alanların kesişim noktasında ortaya çıkmaktadır.

Araştırmanın bulguları, öğrencilerin eğitim aldıkları alanda çalışmaya istekli oldukları fakat bu alanda iş bulma konusunda umutsuzluk yaşadıklarını işaret etmektedir. Yanı sıra, öğrencilerin büyük çoğunluğu sektörde çalışma koşullarının kötü ve ücretlerin yetersiz olduğunu düşünmektedir. Mesleki vasıflara dönük kanaatleri ise sektörde teknik becerilerin önde olduğu fakat mesleğin niteliğini artırmak için entelektüel donanımın da gerekli olduğu yönündedir. 
Öğrencilerin çoğu iletişim fakültesi mezunu olmanın değersizleştiğini düşünmekte fakat buna karşın yine de bu alanda çalışabilmek için eğitim almanın gerekli olduğunu belirtmektedir. Buna paralel olarak öğrencilerin çoğunda aldıkları eğitimle mezun olduktan sonra bir meslek sahibi olacakları inancı hâkimdir. Benzer şekilde, öğrencilerin çoğu eğitimini aldıkları alanda yapacakları işin topluma fayda sağlayacağını düşünmekte fakat bu işin toplum nezdinde yeteri kadar saygınlığa sahip olup olmayacağı konusunda kararsız kalmaktadır.

Aldıkları eğitim konusunda ise öğrencilerin yarısı nitelikli eğitim aldığını düşünürken, beşte biri nitelikli eğitim alamadığını ifade etmektedir. Kendilerini en eksik hissettikleri alanlar uygulamalı eğitim ve yabancı dil eğitimidir. Buna paralel olarak öğrencilerin çok büyük kısmı eğitimleri içerisinde stajın zorunlu olması gerektiğini belirtmiştir. Zorunlu staj isteğinin iş bulma çabası ile ilişkili olduğu düşünülebilir.

Öğrencilerin algı ve beklentileri ile medya emek piyasasının genel durumu arasında önemli bir örtüşme bulunduğu ve öğrencilerin medya emek piyasasının eğilimlerine dönük farkındalıklarının yüksek olduğu belirtilebilir. Bu durumun, öğrencilerin kendi gelecekleri ve ülkenin geleceği konusundaki kavrayışlarını ve umutlarını nasıl şekillendirdiği ise üzerinde düşünülmesi gereken bir nokta olarak öne çıkmaktadır. 


\section{Kaynakça}

Adakl1, Gülseren. 2009. "The Process of Neoliberalisation and the Transformation of the Turkish Media Sector in the Context of the New Media Architecture". Mediating Europe: New Media, Mass Communications and the European Public Sphere içinde, editörler J. Harrison ve B. Wessels, 286-317. New York ve Oxford: Berghahn Books.

Aydın, Uraz. 2014. “The Media in Turkey: From Neoliberal Militarism to Authoritarian Conservatism". Turkey Reframed: Constituting Neoliberal Hegemony içinde, editörler İ. Akça, A. Bekmen ve B. A. Özden, 122-140. London: Pluto Press.

Bailey, Kenneth. 1987. Methods of Social Research. New York: The Free Press.

Bulut, Selda. 2020. "The Political Economy of News Production". Handbook of Research on the Political Economy of Communications and Media içinde, editörler S. Karlıdağ ve S. Bulut, 98-114. USA: IGI Global.

Can, Serap. 2018. “İletişim Eğitiminde Akademi ve Sektör Beklentileri Üzerine Bir Araştırma". Humanities Sciences (NWSAHS) 13(3): 57-73.

Çamuroğlu Çı̆̆, Eylem ve Çı̆̆, Ünsal. 2015. “Gazetecilik Emeğinin Prekarizasyonu: Yeni Medya Çağında Habercilik Etiğini Tartışmak". İş Ahlakı Dergisi 8: 197232.

Davies, Bronwyn, Gottsche, Michael ve Bansel, Peter. 2006. “The Rise and Fall of the Neo-Liberal University". European Journal of Education 41(2): 305-319.

Demir, A. Sevtap. 2019. “Türkiye'deki Dijital Doğumlu Gazeteler ve İş Modelleri”. Doktora tezi, Ankara Üniversitesi.

Ekşioğlu Sarılar, Naciye Beril. 2016. “Profesyonel Gazetecilerin Tanıklığında Medyaİktidar-Demokrasi İlişkisi: 2002-2015 Dönemi". Doktora tezi, Maltepe Üniversitesi.

Ercan, Fuat. 1998. Eğitim ve Kapitalizm: Neo-Liberal Eğitim Ekonomisinin Eleştirisi. İstanbul: Bilim Yayınları.

Eurostat. 2019. "The Higher The Education, The Lower The Unemployment Rate". Erişim tarihi 20 Eylül 2020. https: / / ec.europa.eu/ eurostat/web/products-eurostat-news/-/DDN20190920-1 inheritRedirect $=$ true\&redirect $=\% 2$ Feurostat $\% 2$ Fhome $\% 3 \mathrm{~F}$ 
Federal Reserve Bank of New York. 2020. “The Labor Market for Recent College Graduates". Erişim tarihi 15 Ekim 2020.

https: / / www.newyorkfed.org/research/college-labor-market/college-labormarket unemployment.html

Geray, Haluk. 2011. Toplumsal Araştırmalarda Nicel ve Nitel Yöntemlere Giriş. Ankara: Genesis Yayınları.

Gökçe, Birsen. 1988. Toplumsal Bilimlerde Araştırma. Ankara: Savaş Yayınları.

ILO. 2020. “Dünyada İstihdam ve Sosyal Görünüm: Eğilimler 2020”. Erişim tarihi 18 Ekim 2020.

https://www.ilo.org/ankara/news/WCMS 734873/lang--tr/index.htm

IDA. 2016. "PR sektöründe yarışmacı sayısı artıyor!” Erişim tarihi 16 Eylül 2020. https: / / www.marketingturkiye.com.tr/haberler/pr-sektorunde-yarismacisayisi-artiyor/

İnal, Kemal. 2003 “Neoliberal Eğitim ve Yeni İlköğretim Müfredatının Eleştirisi”. Praksis 14: 265-287.

Kaya, A. Raşit. 1999. “Türkiye'de 1980 Sonrası Medyanın Gelişimi ve İdeoloji Gereksinimi". Türk-İş Yıllı̆̆g '99, 2. Cilt, Ankara: Türk-İş Yayınları. Erişim tarihi 10 Eylül 2020.

http://www.dorduncukuvvetmedya.com/arsiv/akaya.htm

Kaya, Şehriban. (2016) “Yeni Türkiye'de Medya”. Yeni Türkiye'nin Toplumsal Yapısı içinde, editör İ. Kaya, 245-274. Ankara: İmge Kitabevi.

Kızılca, F. Kemal.; Karagöz-Kızılca, Gül. 2018. “Türkiye'de İletişimciler ve ‘Preker' Emek: Gözden Kaçmış Bir Veri Tabanından Bulgular". Galatasaray Üniversitesi İletişim Dergisi 29: 9-30.

Önderoğlu, Erol. 2015. “Medyanın 3 Yılı: Grafik Özet”. Erişim tarihi 5 Eylül 2020. http:/ / bianet.org/bianet/medya/162748-medyanin-3-yili-grafik-ozet

RATEM. 2019. “Türkiye Radyo ve Televizyon Yayıncılığı Sektör Raporu”. Erişim tarihi 16 Eylül 2020.

https: / / www.ratem.org/ratem-sektor-raporlari

Rikowski, Glenn. 2018. "Marxism and Education: Fragility, Crisis, Critique". Cadernos GPOSSHE On-line 1(1): 142-170.

Sayılan, Fevziye. 2006. “Küresel Aktörler (DB ve GATS) ve Eğitimde Neo-Liberal Dönüşüm”. TMMOB Jeoloji Mühendisleri Odası Haber Bülteni 4, Erişim tarihi: 11 Ekim 2020.

https:/ / www.jmo.org.tr/resimler/ekler/1e03cc77d4bbd6b_ek.pdf 
Seçkin, Gülcan. 2020. "The Integration of the Media With the Power in Turkey (2002-2019): Native, National Media Conception". Handbook of Research on the Political Economy of Communications and Media içinde, editörler S. Karlıdağ ve S. Bulut, 206-226. USA: IGI Global.

SGK. 2019a. "İstatistik Yıllıkları”. Erişim tarihi 5 Eylül 2020.

http://www.sgk.gov.tr/wps/portal/sgk/tr/kurumsal/istatistik/sgk $\underline{\text { istatistik yilliklari }}$

SGK. 2019b. "Kayıtdışı İstihdam Oranları". Erişim tarihi 4 Eylül 2020.

http://www.sgk.gov.tr/wps/portal/sgk/tr/calisan/kayitdisi_istihdam/ kayitdisi istihdam oranlari/kayitdisi istihdam orani

Sönmez, Mustafa. 2013. Medya Kültür Para ve İstanbul İktidarı. İstanbul: Yordam Kitap.

Sözeri, Ceren. 2015. Türkiye'de Medya-İktidar İlişkileri: Sorunlar ve Öneriler. İstanbul: İstanbul Enstitüsü. Erişim tarihi 2 Eylül 2020. http://platform24.org/Content/Uploads/Editor/ T\%C3\%BCrkiye $\%$ E2\% 80\%99de $\% 20$ Medya-\%C4\%B0ktidar\%20 \%C4\%B0li\%C5\%9Fkileri-BASKI.pdf (Erișim: 13.09.2020).

Torres, Carlos. A. ve Schugurensky, Daniel. 2002. “The Political Economy of Higher Education in The Era of Neoliberal Globalization: Latin America in Comparative Perspective". Higher Education 3(4): 429-455.

TÜİK. 2020a. “İşgücü İstatistikleri”. Erişim tarihi 5 Eylül 2020. http://www.tuik.gov.tr/PreTabloArama.do?metod=search\&araType=hb x

TÜİK. 2020b. “Yazılı Medya İstatistikleri”. Erişim tarihi 5 Eylül 2020.

http://www.tuik.gov.tr/PreTabloArama.do? metod=search\&araType=hb_x

TÜİK. 2020c. "Yıllık Sanayi ve Hizmet İstatistikleri”. Erişim Tarihi 6 Eylül 2020.

http: / / www.tuik.gov.tr / PreTabloArama.do? $\operatorname{metod}=$ search\&araType $=$ hb $\mathrm{x}$

Uzunoğlu, Sarphan. 2018. “Gazeteci Emeğinin Dönüşümü ve Güvencesizleşme:

Türkiyeli Dijital Haber Odalarının Serbest Muhabirleri Üzerine Bir Çalışma”. Moment Dergi 5(2): 195-218.

Ünal, Iş11. 2005. “'İktisat İdeolojisi'nin Yeniden Üretim Süreci Olarak Eğitim”.

Ekonomik Yaklaşım 16(57): 35-50.

Ünal, Iş11. 2013. “Kapitalist Toplumda Eğitim: Kuram ve Gerçekliğe Genel Bir Bakış”. Praksis 33: 9-27.

YÖK. 2020. "Yükseköğretim İstatistikleri”. Erişim tarihi 1 Ekim 2020.

https://istatistik.yok.gov.tr/ 